\title{
Efficacy of Nutritional Interventions as Stand-Alone or Synergistic Treatments with Exercise for the Management of Sarcopenia
}

\author{
Sarah Damanti ${ }^{1,2,+}{ }^{+}$Domenico Azzolino ${ }^{1,2, *, \dagger}$, Carlotta Roncaglione ${ }^{1}$, Beatrice Arosio ${ }^{1,3}$, \\ Paolo Rossi ${ }^{1}$ and Matteo Cesari ${ }^{1,3}$ (D) \\ 1 Geriatric Unit, Fondazione IRCCS Ca' Granda Ospedale Maggiore Policlinico, 20122 Milan, Italy \\ 2 Phd Course in Nutritional Sciences, University of Milan, 20122 Milan, Italy \\ 3 Department of Clinical Sciences and Community Health, University of Milan, 20122 Milan, Italy \\ * Correspondence: domenico.azzolino@policlinico.mi.it \\ + These authors contributed equally to this work.
}

Received: 31 July 2019; Accepted: 20 August 2019; Published: 23 August 2019

\begin{abstract}
Sarcopenia is an age-related and accelerated process characterized by a progressive loss of muscle mass and strength/function. It is a multifactorial process associated with several adverse outcomes including falls, frailty, functional decline, hospitalization, and mortality. Hence, sarcopenia represents a major public health problem and has become the focus of intense research. Unfortunately, no pharmacological treatments are yet available to prevent or treat this age-related condition. At present, the only strategies for the management of sarcopenia are mainly based on nutritional and physical exercise interventions. The purpose of this review is, thus, to provide an overview on the role of proteins and other key nutrients, alone or in combination with physical exercise, on muscle parameters.
\end{abstract}

Keywords: sarcopenia; nutrition; physical exercise; synergism; older people

\section{Sarcopenia}

Muscle mass and strength progressively decline after the age of 40 . Then, these age-related changes substantially accelerate after the age of 60 , especially in the presence of sedentary behavior and comorbidities [1]. This clinical manifestation of aging is called sarcopenia (from the Ancient Greek

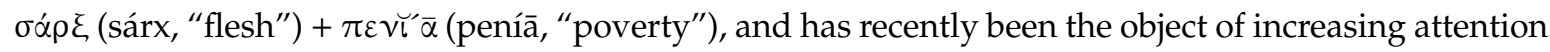
from researchers, clinicians, and public health authorities. Its growing relevance is paradigmatically exemplified by the recent inclusion of a specific ICD-10 code for it [2].

Contrary to lean mass decline, there is an increase in fat mass, with aging [3]. Adipose tissue can infiltrate muscles both at macroscopic (between muscle groups) and microscopic level (between and inside myocytes) with a further reduction in muscle mass and quality [4].

Sarcopenia represents an important sanitary problem since it affects $20 \%$ of people over 70 and $50 \%$ of people over 80 [5]. Moreover, considering the important function of muscle tissue beyond locomotion (e.g., influence on glucose and protein metabolism and on bone density) [6], it is associated with many adverse clinical outcomes (falls, fractures, functional and cognitive decline, cardiac and respiratory disease, reduced quality of life and independence, hospitalization, and mortality) [7-19]. Therefore, an early detection and treatment of this condition is pivotal.

In recent years, many studies have consistently demonstrated that muscle strength declines more rapidly $(1.5 \%-5 \%$ year after the age of 50$)$ than muscle mass ( $1 \%-2 \%$ year after the age of 50$)[1,20-27]$, allowing an earlier identification of muscle impairment. Moreover, muscle strength correlates better 
than muscle mass with adverse health outcomes [28]. Therefore, in 2009, the European Working Group on Sarcopenia in Older People (EWGSOP) met to elaborate a definition of sarcopenia, which included both the presence of low muscle mass and function [29]. Sarcopenia was defined as a geriatric syndrome characterized by a progressive loss of muscle mass and strength. However, recently this definition has been updated [30] in light of the recognition of the role as disease of sarcopenia and of the scientific advantages, which stress the role of muscle strength as a principal determinant of the condition. Sarcopenia is now defined as a muscle disease, which can be considered probable if reduced muscle strength is detected. The main tools used to assess muscle strength are the hand grip dynamometer [31] or the chair stand test [32,33]. The diagnosis is confirmed in the presence of reduced muscle mass. The main instrument to assess muscle mass used for research purpose is the dual-energy X-ray absorptiometry (DXA). Bioelectrical impedance analysis [34] is another possibility, though less precise and more sensitive to body water content changes. Finally, in selected settings (i.e., oncologic patients), abdominal CT scans [35] performed for other purposes can be employed to estimate body muscle mass. Instead, anthropometric measures (i.e., calf circumference), though easy to assess, are not considered a reliable measure of muscle mass [36].

The severity of the condition can be then graded by measuring muscle performance. The most common used tools are the Short Physical Performance Battery32, the timed 'up and go' test [37], and the $400 \mathrm{~m}$ walking test [38].

Several mechanisms concur to the development of sarcopenia, including malnutrition, hormonal changes (i.e., reduction of growth hormone, estrogens, and testosterone), increased production of pro-inflammatory cytokines (also by the adipose tissue infiltrating the muscle [9]), higher muscle protein breakdown, myocytes loss, reduced satellite cell replenishment, loss of $\alpha$-motor neurons, muscular mitochondrial dysfunction, altered myocyte autophagy, accelerated apoptosis of myonuclei, and impaired satellite cell function. Recently, the role of the fibromodulin has been highlighted, which is an extracellular matrix protein and predominantly controls a wide range of myogenesis-related genes (i.e., myogenin, myosin light chain 2, and transcriptional activity of myostatin) [39,40]. Fibromodulin is an essential part of the myogenic program and its role in the regulation of myoblasts may help in the development of new therapeutic agents (i.e., novel myostatin inhibitors) for the treatment of different muscle atrophies like as sarcopenia $[39,40]$. Furthermore, insulin resistance reduces the ability to use the available proteins [41]. Insulin resistance in the skeletal muscle results in whole-body metabolic disturbances associated with type 2 diabetes, which are further exacerbated by sarcopenia [42,43]. All these alterations are differently responsible for an imbalance between the anabolic and catabolic process at the muscular level [44]. Nevertheless, this list of pathophysiological pathways has to be considered as non-exhaustive, especially because novel mechanisms are under study and continuously propose novel/complementary possibilities. Pathophysiological mechanisms represent a possible target for therapeutic interventions.

\section{Nutritional Interventions}

Malnutrition is a state resulting from the lack of intake or uptake of nutritional elements, which alters body composition and body cell mass. Its etiologies can be heterogeneous: Starvation [45], cachexia [46], or simply aging [47]. Malnutrition has serious consequences, thus impairing both physical and mental functions and predisposing to adverse clinical outcomes from diseases [48]. Indeed, reduced intake of specific nutrients compromises the anabolic signal to muscles whereas their altered uptake configures a situation of anabolic resistance. Both conditions contribute to the development of sarcopenia [49].

Recently, the European Society of Clinical Nutrition and Metabolism (ESPEN) has validated the new diagnostic criteria for malnutrition [50]. The diagnosis can be performed if body mass index (BMI) is $<18.5 \mathrm{~kg} / \mathrm{m}^{2}$ or if an unintentional weight loss is associated with either a reduced BMI $\left(<20 \mathrm{~kg} / \mathrm{m}^{2}\right.$ in younger or $<22 \mathrm{~kg} / \mathrm{m}^{2}$ in older patients) or a low-fat free mass index. Moreover, malnutrition should be screened in all individual who are potentially at risk. 


\subsection{Proteins and Essential Amino Acids}

Dietary proteins stimulate skeletal muscle protein synthesis and inhibit muscle protein breakdown [51-53]. Some observational studies have showed an association between protein intake and muscle mass and strength [54-56].

The effect of protein supplementation has been particularly evident on muscle strength and function [57] rather than on mass. However, protein supplementation alone could not be sufficient in cases of severe catabolism [58].

Older people frequently fail to reach the recommended dietary allowance (RDA) of proteins and calories. First of all, there is a reduction in appetite with aging, the so-called "anorexia of aging" [59,60]. Moreover, eating habits change due to swallowing and/or economic problems. Thus, the consumption of proteins rich nutrients switches in favor of energy-dilute foods (grains, vegetables, and fruits) [61].

Recently, two consensus studies (ESPEN [62] and PROT-AGE study group [41]) have stated that the traditional RDA of proteins for adults of all ages $(0.8 \mathrm{~g} / \mathrm{kg}$ body weight/day [63]) was not sufficient for older people. People aged 65 and older need more proteins to activate the muscle protein synthesis, compared to younger people [41,64]. Actually, older people have to counteract an anabolic resistance underpinned by an increased splanchnic sequestration of amino acids, lower postprandial perfusion of muscles, decreased muscle uptake of dietary amino acids, reduced anabolic signaling for protein synthesis, and an impaired digestive capacity $[41,65,66]$. Moreover, they require more proteins to offset inflammatory and catabolic conditions associated with chronic and acute diseases [67]. Thus, both the ESPEN and the PROT-AGE group concord in suggesting the assumption of 1-1.2 $\mathrm{g}$ proteins $/ \mathrm{kg}$ body weight/day. A high-protein diet does not damage the kidney in healthy old individuals [68,69], whereas people with a severe kidney disease who do not undergo dialysis should limit their protein intake at about $0.8 \mathrm{~g} / \mathrm{kg}$ body weight/day [41].

The protein source and amino acid composition are also important: Plant proteins have a lower anabolic effect compared to animal proteins [70], probably because they have a lower content of leucine. Moreover, independently from the amino acid content, proteins could have different absorption kinetics, which could influence their anabolic effect. There is a debate whether slow or fast digested proteins could better influence a muscle synthetic response [71-73]. It seems that fast proteins are more effective in stimulating muscle protein accretion41 even if results should be confirmed in larger trials.

Spread feeding patterns, in which an equal amount of protein is ingested at each meal, seems to optimize the protein synthetic capacity [74]. Nevertheless, some studies have also showed that with pulse feeding (with a main high protein meal), anabolic benefits can be reached [75,76]. Thus, additional trials are needed to establish the optimal timing of protein administration.

Moreover, some proteins are metabolized to short-chain fatty acids (like propionate, butyrate, and acetate) which are used by muscle cells to produce energy [77-80]. Indeed, short-chain fatty acids promote muscle anabolism and display anti-inflammatory proprieties positively, influencing muscle health [81-84].

Essential amino acids (EAAs), in particular leucine, are an important anabolic stimulus, too [85]. The main dietary sources of EEAs are lean meat, dairy products, soybeans, cowpeas, and lentils. The biological pathways on which leucine act are the activation of the mammalian target of rapamycin (mTOR) [86] and the inhibition of the proteasome [87]. However, supplementation with high doses of EEAs (10-15 g) and leucine (at least $3 \mathrm{~g}$ ) is necessary to overcome anabolic resistance in older people [88].

A recent meta-analysis has confirmed that leucine is able to increase muscle protein synthesis in older people [89] and its consumption has been found to be directly correlated with muscle mass retention in healthy older people [90]. What is more, the supplementation with EAA in older people has been effective in increasing both muscle mass and function [91]. 


\section{2. $\beta$-Hydroxy $\beta$-Methylbutyrate}

B-hydroxy B-methylbutyrate (HMB) is one of the metabolites of leucine, which exerts anabolic effects through the activation of the mTOR pathway and the stimulation of the growth hormone/IGF-1 axis [92]. HMB also has anticatabolic effects: It decreases ubiquitin-proteasome expressions $[93,94]$ and attenuates the up-regulation of caspases [95]. Moreover, it increases mitochondrial biogenesis and fat oxidation [96], possibly contributing to the improvement of muscle performance. HMB also favors sarcolemmal integrity via its conversion into hydroxymethylglutaryl-CoA [97]. Therefore, its final effects are induction of myogenic proliferation and differentiation [98]. Only $5 \%$ of leucine is usually metabolized to HMB [99] and there is an age-related decline in its concentrations [100]. Thus, there is a rationale for supplementation with HMB in old sarcopenic individuals. HMB is frequently used by athletes to better their physical performance [101]. It has been shown to be effective in improving muscle mass and strength in older adults too. What is more, $\mathrm{HMB}$ contributes to the preservation of muscle mass during bed rest, a known wasting condition [102-105].

\subsection{Ornithine $\alpha$-Ketoglutarate}

Ornithine $\alpha$-ketoglutarate (OKG) is a compound formed by ornithine (a non-proteinogenic amino acid) and $\alpha$-ketoglutarate (a keto acid derived from the deamination of glutamate). It can offset sarcopenia through various mechanisms. OKG is the precursor of many amino acids (glutamate, glutamine, arginine, and proline), and of nitric oxide (NO), which improves hemodynamics in skeletal muscles [106]. Furthermore, it acts as a secretagogue of anabolic hormones like insulin and the growth hormone $[106,107]$. Therefore, OKG has successfully been used in experimental conditions of hypercatabolism (e.g., malnutrition, cancer cachexia, burn injury, and surgery) to reduce muscle wasting [108-111]. However, its effects have not been investigated yet, in non-malnourished older people.

\subsection{Vitamin $D$}

Deficit of vitamin D has been associated with reduced muscle mass and strength in prospective studies [112,113]. Most older people have serum levels of vitamin D below the normal range. The etiology of this deficit is multifactorial: Insufficient dietary intake, inadequate sunshine exposure, altered skin synthesizing capacity, and diminished renal conversion to the active form [114]. Moreover, there is a reduction in the expression of vitamin D receptors on muscle tissue $[115,116]$ with aging.

The effects of vitamin D are mediated by its link with nuclear (VDR) and membrane-bound vitamin D receptors. The former activate the transcription of target genes involved in calcium uptake, phosphate transport, satellite cells proliferation, and terminal differentiation [117] while the latter regulate the release of calcium into the cytosol, respectively. This is pivotal for muscle contraction and induces protein synthesis [118].

Vitamin D supplementation can modulate the expression of VDR [119] with positive effects on muscle performance and strength $[120,121]$. What is more, it also improves muscle fiber composition and morphology [122]. Curiously, benefits seem to be appreciable only in people with low levels of vitamin D.

Therefore, it is recommended to dose vitamin D in all sarcopenic patients and to prescribe supplements in those who are deficient. Promotion of an adequate sunshine exposure together with the consumption of foods rich in vitamin D (salmon, mackerel, herring, sun-dried mushrooms) should instead be suggested in all older people.

\subsection{Creatine Monohydrate}

Creatine ( $\mathrm{Cr}$ ) is a compound that can be assumed with food (lean red meat, tuna, and salmon) or can be synthetized endogenously in the liver and kidneys using the amino acids glycine, arginine, and methionine. 
Most of the creatine is stored in the skeletal muscles where it is converted into a high-energy metabolite phosphocreatine (PCr) by the enzyme creatine kinase. PCr acts as an energy buffer: At the beginning of muscular contraction, it donates a phosphate group to ADP to form ATP in order to produce energy anaerobically. During rest, the opposite process takes place and the excess of ATP is used to regenerate $\mathrm{PCr}$ from $\mathrm{Cr}[123,124]$.

Moreover, $\mathrm{Cr}$ activates the transcription of genes involved in muscle protein synthesis and satellite cells activation probably mediated by the mTOR pathway [125-127]. In fact, creatine may enhance muscle mass and force probably by increasing the expression of IGF-1 $[127,128]$, which seems to activate the key elements of protein synthesis of the IGF1-IRS1-PI3K-AKT-mTOR pathway [129-131]. Indeed, it is well known that the activation of the IGF1-IRS1-PI3K-AKT-mTOR pathway induces muscle hypertrophy $[132,133]$. The consequent increase of IGF-1 via $\mathrm{Cr}$ is also observable in the significantly increased expression of several myogenic regulatory factors (i.e., Myo-D, Myf-5 and MRF-4) [128], which are responsible for satellite cell activation, proliferation, and differentiation [134]. This positive effect of creatine on muscle is probably only observable together with exercise [135-137]. Just recently, Ferretti et al. [138] demonstrated that during resistance training, Cr monohydrate increases muscle size and performance, suggesting a higher activation of muscle protein synthesis via IGF1-IRS1-PI3K-AKT-mTOR pathway.

Considering that in older people intramuscular Cr levels are reduced [139], the supplementation with $\mathrm{Cr}$ could be very beneficial. Indeed, there is evidence that high consumption of creatine can improve muscle mass and functions in older people [140].

\subsection{Antioxidants and polyunsaturated fatty acids}

Aging is characterized by oxidative stress-induced damages in various organs and systems [141].

In the pathogenesis of sarcopenia, there is an oxidative damage to muscle mitochondria and membranes, which compromises ATP production and increases sarcolemma permeability. Both alterations cause energy deprivation and activate stress pathways, which lead to muscle cell apoptosis [142-145].

The base of this damage is an imbalance between reactive oxygen species production and antioxidant defenses. Supplementation of exogenous antioxidants has been proposed in older people, since it can help the action of endogenous antioxidant enzymatic systems (i.e., superoxide dismutase, glutathione peroxidase)

It is true that high-plasma carotenoids have been associated with a lower risk of developing walking disability and decline in muscle strength in community-dwelling older people $[146,147]$. Anyway, excessive vitamin $C$ and $E$ supplementation can compromise muscular adaptations to strength training in older people [148]. This is because a limited ROS production is pivotal to promote adaptation to exercise [149]. In fact, it favors force production and mitochondrial biogenesis [150,151]. Excessive antioxidant supplementation in people who are not deficient could therefore compromise the mechanism of adaption to exercise. Thus, the supplementation can have a final negative effect on muscle mass and performance.

Moreover, many antioxidants (like selenium, vitamin $A$, vitamin $C$, vitamin $E$, and $\beta$-carotene) can also behave as potent pro-oxidants under some circumstances [152]. This is one more reason why supplementation with antioxidant in people who are not deficient can blunt the beneficial effects of physical exercise [153]. Meta-analyses and systematic reviews have demonstrated an increased mortality in both healthy people and those with various diseases who have been supplemented with antioxidants [154-156]. Considering the possible harms of antioxidant supplementation, its use to prevent or treat sarcopenia should be avoided unless an overt deficit is documented [157]. Instead, promoting the regular consumption of foods naturally rich in antioxidant could be beneficial in older people [158].

Supplementation with polyunsaturated fatty acids (PUFAs), and in particular with omega-3 fatty acids, improves muscle protein anabolism. PUFAs seem to directly act on mTOR signaling [159] and 
reduce inflammation $[160,161]$. The main dietary source of PUFAs is fatty fish: Salmon, mackerel, herring, lake trout, sardines, albacore tuna, and their oils. A higher dietary consumption of PUFAs has been associated with a greater fat-free mass [162]. A positive correlation between fatty fish (which is rich in PUFA) and grip strength was found in community-dwelling older people [163] too.

However, many studies on supplementation with PUFAs (with different dosages and for different periods) have produced different but mainly inconsistent results so far [164,165]. Moreover, the risk for potential adverse events associated with long-term supplementation has not been clearly elicited. Therefore, there is insufficient evidence to promote the systematic consumption of PUFAs in sarcopenic individuals.

\subsection{Ursolic Acid}

Ursolic acid is a compound with anti-inflammatory properties, which is abundant in apple peels, plum, cranberry, blueberry, rosemary, hawthorn, thyme, basil, oregano, and peppermint [166].

In murine models, ursolic acid has displayed anabolic proprieties mediated by the repression of atrophy-associated genes (atrogin-1 and MuRF1), and the induction of trophic genes (PKB/Akt and S6 kinase). Furthermore, it was able to stimulate the insulin/IGF-1 axis producing muscular hypertrophy [167]. However, supplementation in sarcopenic individuals has not been performed yet.

\subsection{Nitrate-Rich Foods}

Nitrate (NO3-)-rich foods (e.g., celery, cress, chervil, lettuce, red beetroot, spinach, and rocket) have a potential role in the treatment of sarcopenia. Food-derived NO3- is reduced to NO2- by commensal bacteria of the oral cavity [168]. Through several mechanisms, NO2-is then converted to nitric oxide (NO), which is the active mediator of the anti-sarcopenic effects of these compounds. The increase in gastric levels of NO attenuates the aging anorexia by reducing the earlier satiety feeling [59]. Furthermore, by improving the endothelial function, NO improves nutrient supply to muscles [169].

Finally, NO optimizes mitochondrial bioenergetics, by reducing the metabolic cost of exercise [170,171]. Indeed, NO was effective in improving muscular performance in young individuals [172]. On the contrary, short-term supplementation with nitrate-rich foods did not improve muscular performance and strength [173] in older people. Thus, there has been insufficient evidence so far to recommend the supplementation with nitrate-rich foods in sarcopenic individuals.

\subsection{Prebiotics, Probiotics, and Symbiotics}

Recently, gut microbiota has been proposed as a contributor in the pathogenesis of sarcopenia, so interventions that promote its health can be beneficial. Older people tend to develop an intestinal dysbiosis, which is associated with an increased gut permeability. Alterations of the gut barrier facilitate the passage of endotoxins and other microbial products with inflammatory effects into the blood stream. This contributes to the development of a deleterious state of systemic inflammation [174] contributing to muscle wasting $[78,175]$.

Moreover, the reduction of intestinal mobility, typical of older persons, also alters the species of bacteria colonizing the gut (Bacteroidetes and Firmicutes) in favor of species with greater proteolytic potential (Proteobacteria) [176], consequently influencing the proper utilization of dietary proteins [175]. An enhanced proteolytic capacity and anabolic resistance of the gut microbiota, characteristic of older age, have been reported. These mechanisms are probably mediated by the age-related proinflammatory state $[175,177,178]$.

Furthermore, it has been demonstrated in murine models that intestinal dysbiosis can alter neuromuscular transmission with a consequent promotion of muscle protein catabolism [179].

Thus, the administration of prebiotics, probiotics, and symbiotics, substances that improve microbiota health, has been proposed as a possible treatment for sarcopenia. Prebiotics are specific 
fermented ingredients that can induce changes in the composition and/or in the activity of the gastrointestinal microflora with a final beneficial effect for the host organism $[79,180]$.

The actually available prebiotics are non-digestible oligosaccharides (i.e., inulin, oligofructose, (trans)galactooligosaccharides). They modulate the metabolism of the intestinal flora and show immunomodulatory properties [180]. Indeed, a study of Buigues [181] demonstrated that 13-week supplementation with prebiotics improved exhaustion and handgrip strength in older people.

Probiotics are instead viable microorganisms that can exert beneficial effects when administered in adequate quantities for reaching the intestine in an active state [182]. Probiotics modulate the intestinal microflora of the host by reducing microbial aberrancies and having an inflammatory effect [180].

The most used probiotics are Bifidobacteri and Lactobacilli [183]. Indeed, in animal studies, the administration of Lactobacillus reuteri, which modulates the transcriptional factor Forkhead Box N1 (FoxN1), was able to prevent cachexia in murine models of cancer [184]. Other probiotics, like Faecalibacterium prausnitzii, has anti-inflammatory proprieties [185] and in animal models, can improve the marker of oxidative stress [186].

Finally, symbiotics are a combination of prebiotics and probiotics exerting synergic effects [187].

Proteins, which are a known nutritional treatment for sarcopenia, represent a substrate for gut microbiota too.

Proteins increase microbiota diversity [188] and the number of protein-fermenting bacteria, which increase the bioavailability of dietary amino acids $[175,188]$.

Short-chain fatty acids and secondary biliary salty acids, produced by microbiota, may counteract age-related muscle decline, too, thanks to their positive effects on muscle mitochondria. Moreover, they reduce host inflammation by decreasing $\operatorname{TNF} \alpha$-mediated immune responses and inflammasomes (i.e., NLRP3) [78].

We have to underline that the evidence of the effectiveness of prebiotics, probiotics, and symbiotics comes mainly from animal studies. Therefore, further research targeting specifically sarcopenic individuals is needed to recommend their routinely use.

\section{Synergies between Nutritional and Physical Exercise Interventions}

Inactivity is one of the main causes of sarcopenia [189] because it determines a resistance to muscle anabolic stimuli [190]. Therefore, the combination of nutritional interventions and physical exercise acts synergically to improve muscle health. Indeed, up to now it has been the most effective strategy for the management of sarcopenia.

The World Health Organization recommends performing at least $150 \mathrm{~min} /$ week of moderate-intensity physical activity or at least $75 \mathrm{~min} /$ week of vigorous-intensity physical activity or an equivalent combination of the two. An additional benefit can be obtained by increasing the amount of moderate-intensity physical activity to $300 \mathrm{~min} /$ week and by performing strengthening activities involving the major muscle groups on two or more days a week. Furthermore, for people with poor mobility, it is suggested to do exercises to enhance balance and prevent falls on three or more days per week [191]. Since sarcopenia involves muscles in the whole-body $[7,192,193]$ it has been recently recommended to perform an holistic training involving all muscle groups [192].

It is interesting to note that when exercise is proposed to older people, they usually show a positive attitude and also enjoy the social component of the activities [194], even in the hospital setting [195].

The maximum effect of exercise is achieved within the first $3 \mathrm{~h}$ after training, but it can persist up to $24 \mathrm{~h}$ after the bout is over [196].

In particular, resistance training reduces insulin resistance, sensitizes muscles to other anabolic stimuli, and promotes mitochondrial biogenesis [78]. Therefore, resistance training is established to increase the synthesis of myofibrillar proteins in older people [197] with a consequent positive effect on muscle mass, strength, and performance [198-204]. These results are even appreciable at an extremely advanced age (i.e., centenarians) [205-207]. 
There are also potential indirect effects of exercise on gut microbiota that are noteworthy. By affecting intestinal mobility [208], exercise seems to reduce the dysbiosis, which negatively impacts muscle protein anabolism $[209,210]$.

Here, we revise the major nutritional interventions that showed to have a synergic effect with physical exercise.

\subsection{Protein/Amino Acid and Exercise}

Exercise sensitizes the muscle to the anabolic actions of amino acids [211]. Indeed, the combination of protein/amino acid administration with physical exercise has proved to augment muscle protein anabolism compared to each intervention alone [212]. The synergistic effect is appreciable both in young and older people [213]. The sensitizing effect of exercise to amino-acid anabolic effects is maximal $3 \mathrm{~h}$ after the physical effort [211]. Therefore, proteins should be assumed $2-3 \mathrm{~h}$ after training [41]. Both resistance $[73,197,214]$ and aerobic exercise $[215,216]$ improve the protein anabolic stimulus. The effect is appreciable even if the intensity of exercise is only moderate [215]. Indeed, a metanalysis of 22 randomized controlled trials have confirmed that the combination of protein supplementation with resistance training has produced a greater increase in fat-free mass, type I and II muscle fiber cross-sectional area, and muscle strength compared to exercise alone [217]. These results have partially been endorsed by a more recent systematic review [218]. This review has included heterogeneous studies in terms of populations, duration, and dose of daily proteins. There have been negative findings in some of the included studies. These were mainly in older participants already with a sufficient protein and caloric intake and in people receiving soy proteins.

In summary, combination of protein/EAAs supplementation should be recommended in people who are deficient in association with physical exercise to prevent and reverse sarcopenia.

\section{2. $H M B$ and Exercise}

The rationale for associating HMB supplementation and exercise is that HMB seems to promote the regenerative capacity of skeletal muscles after high-intensity exercise. Attenuation of markers of skeletal muscle damage after exercise were seen in case of administration of HMB [219]. Moreover, in one study, supplementation with HMB in association with strength training in older people increased more muscle mass and strength compared to exercise alone [220].

HMB effects are mainly appreciable in untrained people undergoing strenuous exercise, but also in trained people performing high physical stress training [95].

Indeed, a recent systematic review [221] has shown that the association of HMB plus resistance training enhances training-induced muscle mass and strength, attenuates markers of muscle damage, and improves markers of aerobic fitness. However, in another systematic review, the additional effect of HMB plus exercise was found only in one out of three randomized controlled trials for muscle mass and no additional effect was demonstrated for muscle strength and performance [218]. These negative findings can be explained by the fact that the suppression of proteolysis mediated by HMB may blunt the adaptation to training [95]. Moreover, a long period of pre-exercise supplementation may be necessary to achieve results [222].

\subsection{Creatinine and Exercise}

Considering the role of creatinine as energy buffer, it appears to be particularly useful in high-intensity exercise. The creatine-phosphocreatine system is highly used during these performances, so it can provide energy at a rapid rate.

The combination of $\mathrm{Cr}$ supplementation and resistance training increases IGF-1 at muscular level [127]. In turn, IGF-1 favors protein synthesis by activating the central mediator, PKB/AKT; and, subsequently, mTOR [223]. The final effect is an increase in muscle mass and strength, which can continue until 12 weeks after $\mathrm{Cr}$ withdrawal [224]. These results were confirmed both in young [225-228] and older [229-231] adults, though with some conflicting results [229,232-234]. 
Therefore, the PROT-AGE study group suggests supplementation only in older people who are deficient or at high risk of deficiency [41].

\subsection{Vitamin D and Exercise}

Vitamin D has a pivotal role on muscle tropism and function $[235,236]$. The effects of its deficiency on muscles are severe (extreme weakness and muscle pain) [236]. Anyway, in a recent review, no additional effect of vitamin D supplementation plus exercise was found for muscle mass and only conflicting results in terms of muscle performance [203]. Moreover, in the study of Bunout et al. [237], people were supplemented with a dose that was below (400 UI/daily) the recommended daily dose ( $800 \mathrm{UI} /$ daily), while the study of Binder et al. [238] was considered of poor quality. It is reasonable that only individuals who are deficient would display an additional benefit of vitamin D supplementation over exercise. The deficit, causing muscle weakness and pain, would prevent the benefit from exercise training. Supplementation increases vitamin $\mathrm{D}$ receptor expression at muscle level with a positive effect in terms of muscle tropism and performance. Therefore, supplementation creates a positive background for the action of exercise in people who are deficient.

\subsection{PUFA and Exercise}

Results on the synergic effect of PUFA supplementation and exercise on muscle mass and performance are conflicting. In one study, the supplementation with PUFAs (fish oil) plus strength training produced great improvements in muscle strength and performance compared to exercise alone [239]. Anyway, another study has found that 12-week supplementation with $\alpha$ linoleic acid combined with resistance training had only marginal effects on muscle mass and strength [240]. A recent narrative review [241] has concluded that the synergic effect of the two interventions on muscle mass are still equivocal and conflicting about muscle function in older people. Therefore, there is insufficient evidence to recommend this intervention in sarcopenic individuals.

\subsection{Practical Application}

It is well known that older adults frequently have health-related problems, which may compromise the capacity to perform exercise tasks. Furthermore, since it has been shown that individual responses to nutrition/exercise interventions may be quite variable, a personalized approach to counteract muscle decline seem to be promising [242]. As mentioned above, resistance training is the most effective type of exercise to counteract and/or reverse sarcopenia. However, various training-related parameters (i.e., frequency, duration, intensity, volume, etc.), specifics for the older person, need to be considered in the implementation of exercise training programs [243].

Resistance training should be supervised both for compliance and safety (especially for those who are frail or sarcopenic) [244,245]. Furthermore, the time of intervention should be of at least three months to obtain significant improvement in muscle parameters (i.e., muscle strength and physical performance) [244] and exercise frequency should be of two or more nonconsecutive sessions per week [41]. An exercise duration of 10 to $15 \mathrm{~min}$ per session with eight repetition for each muscle group is considered sufficient to counteract muscle decline in healthy older people [41]. However, in frail and sarcopenic subjects, more time and repetitions may be needed to improve muscle parameters. A high-intensity resistance training (i.e., $80 \%-95 \% 1$ repetition maximum) is recommended to induce maximum muscle hypertrophy or muscle fiber adaption [246,247]. Some authors reported that high-intensity resistance training is tolerated in older adults [206,248-250]. Unfortunately, this exercise intensity may not be achieved by frail subjects [251]. Nevertheless, lower intensities of exercise training (i.e., from $50 \%$ to $75 \%$ ) may be sufficient to induce strength gains [192,243].

In a recent systematic review, Liao et al. [251] reported that protein supplementation, in addition to muscle strengthening exercise, is effective in promoting gain both in muscle mass and strength and enhancing physical performance in older adults with a high risk of sarcopenia or frailty. 
In addition to increasing dietary protein intake to at least $1.2 \mathrm{~g}$ protein $/ \mathrm{kg}$ of $\mathrm{BW}$ or providing supplements, it is recommended to supplement proteins or EEAs close after exercise sessions (i.e., $20 \mathrm{~g}$ of proteins) [41]. Nutritional status should be assessed before each intervention and the amount of proteins should be individually adjusted with regard to nutritional status, physical activity level, disease status, and tolerance [252].

\section{Conclusions}

The severe adverse consequences of sarcopenia and their impact on individuals and health systems make the treatment of this condition compelling. Importantly, the complexity of its pathogenesis represents a challenge for its management. Unfortunately, a contemporary pharmacological therapy is not yet available. However, nutritional interventions have shown to produce important beneficial effects on muscle parameters in older adults. Moreover, new dietary components with promising effects are emerging (i.e., gut microbiota manipulation). What is more, promotion of physical exercise according to the WHO guidelines is another efficacious modality considering the beneficial synergisms of nutritional and physical interventions.

In conclusion, sarcopenic individuals should assume 1-1.2 $\mathrm{g}$ proteins/ $\mathrm{kg}$ body weight/day, with high content of EEAs (10-15 g) and leucine (at least $3 \mathrm{~g}$ ) preferentially 2-3 h after exercise to maximize their anabolic effect. Older individuals who are deficient or at high risk of deficiency of vitamin $\mathrm{D}$, creatinine, and HMB should be integrated.

Personalization of the diet and exercise programs according to patients' needs remain the pivotal step for the treatment of sarcopenia. Moreover, preventive strategies to maximize the peak of muscle mass during the adulthood and reduce midlife muscle mass decline should be promoted configuring a life course approach to this condition, so that muscle function is preserved for as long as possible; and, thus positively affecting quality of life and health span.

Author Contributions: S.D. and D.A. equally contributed to conceptualizing and writing the manuscript. C.R., B.A., P.R., and M.C. edited and revised manuscript. S.D., D.A., C.R., B.A., P.R., and M.C. approved the final version of manuscript.

Funding: This research received no external funding.

Conflicts of Interest: The authors declare no conflict of interest.

\section{References}

1. Hughes, A.V.; Frontera, W.R.; Roubenoff, R.; Evans, W.J.; Singh, M.A.F. Longitudinal changes in body composition in older men and women: Role of body weight change and physical activity. Am. J. Clin. Nutr. 2002, 76, 473-481. [CrossRef] [PubMed]

2. Anker, S.D.; Morley, J.E.; Von Haehling, S. Welcome to the ICD-10 code for sarcopenia. J. Cachex Sarcopenia Muscle 2016, 7, 512-514. [CrossRef] [PubMed]

3. Forbes, G.B. Longitudinal changes in adult fat-free mass: Influence of body weight. Am. J. Clin. Nutr. 1999, 70, 1025-1031. [CrossRef] [PubMed]

4. Naimo, A.M.; Gu, J.K.; Lilly, C.; Kelley, A.G.; Baker, B.A. Resistance Training Frequency Confers Greater Muscle Quality in Aged Individuals: A Brief Nhanes Report. JCSM Clin. Rep. 2018, 3, 1-8. [CrossRef]

5. Thomas, D.R. Sarcopenia. Clin. Geriatr. Med. 2010, 26, 331-346. [CrossRef] [PubMed]

6. Welch, A.A. Nutritional influences on age-related skeletal muscle loss. Proc. Nutr. Soc. 2014, 73, 16-33. [CrossRef]

7. Cruz-Jentoft, A.J.; Sayer, A.A. Sarcopenia. Lancet 2019, 393, 2636-2646. [CrossRef]

8. Akune, T.; Muraki, S.; Oka, H.; Tanaka, S.; Kawaguchi, H.; Tokimura, F.; Yoshida, H.; Suzuki, T.; Nakamura, K.; Yoshimura, N. Incidence of certified need of care in the long-term care insurance system and its risk factors in the elderly of Japanese population-based cohorts: The ROAD study. Geriatr. Gerontol. Int. 2014, 14, 695-701. [CrossRef]

9. Sarcopenia and the Cardiometabolic Syndrome: A Narrative Review-EM|consulte. Available online: https://www.em-consulte.com/en/article/1055336 (accessed on 30 July 2019). 
10. Beaudart, C.; Biver, E.; Reginster, J.Y.; Rizzoli, R.; Rolland, Y.; Bautmans, I.; Petermans, J.; Gillain, S.; Buckinx, F.; Dardenne, N.; et al. Validation of the SarQoL ${ }^{\circledR}$, a specific health-related quality of life questionnaire for Sarcopenia. J. Cachexia Sarcopenia Muscle 2017, 8, 238. [CrossRef]

11. Bischoff-Ferrari, H.A.; Orav, J.E.; Kanis, J.A.; Rizzoli, R.; Schlogl, M.; Staehelin, H.B.; Willett, W.C.; Dawson-Hughes, B. Comparative performance of current definitions of sarcopenia against the prospective incidence of falls among community-dwelling seniors age 65 and older. Osteoporos. Int. 2015, 26, 2793-2802. [CrossRef]

12. Bone, E.A.; Hepgul, N.; Kon, S.; Maddocks, M. Sarcopenia and frailty in chronic respiratory disease. Chronic Respir. Dis. 2017, 14, 85-99. [CrossRef] [PubMed]

13. Chang, K.V.; Hsu, T.H.; Wu, W.T.; Huang, K.C.; Han, D.S. Association Between Sarcopenia and Cognitive Impairment: A Systematic Review and Meta-Analysis. J. Am. Med Dir. Assoc. 2016, 17, e7-e15. [CrossRef] [PubMed]

14. De Buyser, S.L.; Petrovic, M.; Taes, Y.E.; Toye, K.R.C.; Kaufman, J.-M.; Lapauw, B.; Goemaere, S. Validation of the FNIH sarcopenia criteria and SOF frailty index as predictors of long-term mortality in ambulatory older men. Age Ageing 2016, 45, 603-608. [CrossRef] [PubMed]

15. dos Santos, L.; Cyrino, E.S.; Antunes, M.; Santos, D.A.; Sardinha, L.B. Sarcopenia and physical independence in older adults: The independent and synergic role of muscle mass and muscle function. J. Cachexia Sarcopenia Muscle 2017, 8, 245-250. [CrossRef] [PubMed]

16. Malmstrom, T.K.; Miller, D.K.; Simonsick, E.M.; Ferrucci, L.; Morley, J.E. SARC-F: A symptom score to predict persons with sarcopenia at risk for poor functional outcomes. J. Cachexia Sarcopenia Muscle 2016, 7, 28-36. [CrossRef] [PubMed]

17. Morley, J.E.; Abbatecola, A.M.; Argilés, J.M.; Baracos, V.; Bauer, J.; Bhasin, S.; Cederholm, T.; Coats, A.J.S.; Cummings, S.R.; Evans, W.J.; et al. Sarcopenia with Limited Mobility: An International Consensus. J. Am. Med Dir. Assoc. 2011, 12, 403-409. [CrossRef]

18. Schaap, L.A.; van Schoor, N.M.; Lips, P.; Visser, M. Associations of Sarcopenia Definitions, and Their Components, With the Incidence of Recurrent Falling and Fractures: The Longitudinal Aging Study Amsterdam. J. Gerontol. A Biol. Sci. Med. Sci. 2018, 73, 1199-1204. [CrossRef]

19. Steffl, M.; Bohannon, R.W.; Sontakova, L.; Tufano, J.J.; Shiells, K.; Holmerova, I. Relationship between sarcopenia and physical activity in older people: A systematic review and meta-analysis. Clin. Interv. Aging 2017, 12, 835-845. [CrossRef]

20. Frontera, W.R.; Hughes, V.A.; Fielding, R.A.; Fiatarone, M.A.; Evans, W.J.; Roubenoff, R. Aging of skeletal muscle: A 12-yr longitudinal study. J. Appl. Physiol. 2000, 88, 1321-1326. [CrossRef]

21. Keller, K.; Engelhardt, M. Strength and muscle mass loss with aging process. Age and strength loss. Muscles Ligaments Tendons J. 2013, 3, 346-350. [CrossRef]

22. Lauretani, F.; Russo, C.R.; Bandinelli, S.; Bartali, B.; Cavazzini, C.; Di Iorio, A.; Corsi, A.M.; Rantanen, T.; Guralnik, J.M.; Ferrucci, L. Age-associated changes in skeletal muscles and their effect on mobility: An operational diagnosis of sarcopenia. J. Appl. Physiol. 2003, 95, 1851-1860. [CrossRef] [PubMed]

23. Lexell, J.; Taylor, C.C.; Sjöström, M. What is the cause of the ageing atrophy? Total number, size and proportion of different fiber types studied in whole vastus lateralis muscle from 15 to 83-year-old men. J. Neurol. Sci. 1988, 84, 275-294. [CrossRef]

24. Newman, A.B.; Kupelian, V.; Visser, M.; Simonsick, E.; Goodpaster, B.; Nevitt, M.; Kritchevsky, S.B.; Tylavsky, F.A.; Rubin, S.M.; Harris, T.B. Sarcopenia: Alternative Definitions and Associations with Lower Extremity Function. J. Am. Geriatr. Soc. 2003, 51, 1602-1609. [CrossRef] [PubMed]

25. Von Haehling, S.; Morley, J.E.; Anker, S.D. From muscle wasting to sarcopenia and myopenia: Update 2012. J. Cachex Sarcopenia Muscle 2012, 3, 213-217. [CrossRef] [PubMed]

26. Dhillon, R.J.; Hasni, S. Pathogenesis and Management of Sarcopenia. Clin. Geriatr. Med. 2017, 33, 17-26. [CrossRef] [PubMed]

27. Tieland, M.; Trouwborst, I.; Clark, B.C. Skeletal muscle performance and ageing. J. Cachexia Sarcopenia Muscle 2018, 9, 3-19. [CrossRef] [PubMed]

28. Studenski, S.A.; Peters, K.W.; Alley, D.E.; Cawthon, P.M.; McLean, R.R.; Harris, T.B.; Ferrucci, L.; Guralnik, J.M.; Fragala, M.S.; Kenny, A.M.; et al. The FNIH Sarcopenia Project: Rationale, Study Description, Conference Recommendations, and Final Estimates. J. Gerontol. Ser. A Biol. Sci. Med. Sci. 2014, 69, 547-558. [CrossRef] [PubMed] 
29. Cruz-Jentoft, A.J.; Baeyens, J.P.; Bauer, J.M.; Boirie, Y.; Cederholm, T.; Landi, F.; Martin, F.C.; Michel, J.P.; Rolland, Y.; Schneider, S.M.; et al. Sarcopenia: European consensus on definition and diagnosis: Report of the European Working Group on Sarcopenia in Older People. Age Ageing 2010, 39, 412-423. [CrossRef]

30. Cruz-Jentoft, A.J.; Bahat, G.; Bauer, J.; Boirie, Y.; Bruyère, O.; Cederholm, T.; Cooper, C.; Landi, F.; Rolland, Y.; Sayer, A.A.; et al. Sarcopenia: Revised European consensus on definition and diagnosis. Age Ageing 2019, 48, 601. [CrossRef]

31. Roberts, H.C.; Denison, H.J.; Martin, H.J.; Patel, H.P.; Syddall, H.; Cooper, C.; Sayer, A.A. A review of the measurement of grip strength in clinical and epidemiological studies: Towards a standardised approach. Age Ageing 2011, 40, 423-429. [CrossRef]

32. Guralnik, J.M.; Simonsick, E.M.; Ferrucci, L.; Glynn, R.J.; Berkman, L.F.; Blazer, D.G.; Scherr, P.A.; Wallace, R.B. A Short Physical Performance Battery Assessing Lower Extremity Function: Association with Self-Reported Disability and Prediction of Mortality and Nursing Home Admission. J. Gerontol. 1994, 49, M85-M94. [CrossRef] [PubMed]

33. Jones, C.J.; Rikli, R.E.; Beam, W.C. A 30-s Chair-Stand Test as a Measure of Lower Body Strength in Community-Residing Older Adults. Res. Q. Exerc. Sport 1999, 70, 113-119. [CrossRef] [PubMed]

34. Sergi, G.; De Rui, M.; Stubbs, B.; Veronese, N.; Manzato, E. Measurement of lean body mass using bioelectrical impedance analysis: A consideration of the pros and cons. Aging Clin. Exp. Res. 2017, 29, 591-597. [CrossRef] [PubMed]

35. Mitsiopoulos, N.; Baumgartner, R.N.; Heymsfield, S.B.; Lyons, W.; Gallagher, D.; Ross, R. Cadaver validation of skeletal muscle measurement by magnetic resonance imaging and computerized tomography. J. Appl. Physiol. 1998, 85, 115-122. [CrossRef] [PubMed]

36. Tosato, M.; Marzetti, E.; Cesari, M.; Savera, G.; Miller, R.R.; Bernabei, R.; Landi, F.; Calvani, R. Measurement of muscle mass in sarcopenia: From imaging to biochemical markers. Aging Clin. Exp. Res. 2017, 29, $19-27$. [CrossRef] [PubMed]

37. Iversen, M.D.; Weyh, A.; Akos, R.; Conzelmann, M.; Dick, W.; Bischoff, H.A.; Stähelin, H.B.; Monsch, A.U.; Von Dechend, M.; Theiler, R. Identifying a cut-off point for normal mobility: A comparison of the timed 'up and go' test in community-dwelling and institutionalised elderly women. Age Ageing 2003, 32, 315-320.

38. Newman, A.B.; Simonsick, E.M.; Naydeck, B.L.; Boudreau, R.M.; Kritchevsky, S.B.; Nevitt, M.C.; Pahor, M.; Satterfield, S.; Brach, J.S.; Studenski, S.A.; et al. Association of Long-Distance Corridor Walk Performance With Mortality, Cardiovascular Disease, Mobility Limitation, and Disability. JAMA 2006, 295, 2018-2026. [CrossRef] [PubMed]

39. Lee, E.J.; Jan, A.T.; Baig, M.H.; Ashraf, J.M.; Nahm, S.S.; Kim, Y.W.; Park, S.Y.; Choi, I. Fibromodulin: A master regulator of myostatin controlling progression of satellite cells through a myogenic program. FASEB J. 2016, 30, 2708-2719. [CrossRef]

40. Jan, A.T.; Baig, M.H.; Malik, A.; Choi, I.; Lee, E.J.; Ahmad, K.; Rabbani, G.; Kim, T.; Park, S.Y. Fibromodulin and regulation of the intricate balance between myoblast differentiation to myocytes or adipocyte-like cells. FASEB J. 2018, 32, 768-781.

41. Bauer, J.; Biolo, G.; Cederholm, T.; Cesari, M.; Cruz-Jentoft, A.J.; Morley, J.E.; Phillips, S.; Sieber, C.; Stehle, P.; Teta, D.; et al. Evidence-Based Recommendations for Optimal Dietary Protein Intake in Older People: A Position Paper From the PROT-AGE Study Group. J. Am. Med. Dir. Assoc. 2013, 14, 542-559. [CrossRef]

42. Ahmad, K.; Lee, E.J.; Moon, J.S.; Park, S.Y.; Choi, I. Multifaceted Interweaving Between Extracellular Matrix, Insulin Resistance, and Skeletal Muscle. Cells 2018, 7, 148. [CrossRef] [PubMed]

43. Cleasby, E.M.; Jamieson, P.M.; Atherton, P.J. Insulin resistance and sarcopenia: Mechanistic links between common co-morbidities. J. Endocrinol. 2016, 229, R67-R81. [CrossRef] [PubMed]

44. Marzetti, E.; Lees, H.A.; Wohlgemuth, S.E.; Leeuwenburgh, C. Sarcopenia of aging: Underlying cellular mechanisms and protection by calorie restriction. BioFactors 2009, 35, 28-35. [CrossRef] [PubMed]

45. Thomas, D.R. Loss of skeletal muscle mass in aging: Examining the relationship of starvation, sarcopenia and cachexia. Clin. Nutr. 2007, 26, 389-399. [CrossRef] [PubMed]

46. Haboubi, N. Assessment and management of nutrition in older people and its importance to health. Clin. Interv. Aging 2010, 5, 207. [CrossRef]

47. Morley, E.J. Anorexia of aging: Physiologic and pathologic. Am. J. Clin. Nutr. 1997, 66, 760-773. [CrossRef] [PubMed]

48. Sobotka, L. Basics in Clinical Nutrition, 5th ed.; Galén: Prague, Czech Republic, 2011. 
49. Trouwborst, I.; Verreijen, A.; Memelink, R.; Massanet, P.; Boirie, Y.; Weijs, P.; Tieland, M. Exercise and Nutrition Strategies to Counteract Sarcopenic Obesity. Nutrients 2018, 10, 605. [CrossRef]

50. Cederholm, T.; Bosaeus, I.; Barazzoni, R.; Bauer, J.; Van Gossum, A.; Klek, S.; Muscaritoli, M.; Nyulasi, I.; Ockenga, J.; Schneider, S.; et al. Diagnostic criteria for malnutrition-An ESPEN Consensus Statement. Clin. Nutr. 2015, 34, 335-340. [CrossRef]

51. Koopman, R.; Verdijk, L.; Manders, R.J.F.; Gijsen, A.P.; Gorselink, M.; Pijpers, E.; Wagenmakers, A.J.M.; Van Loon, L.J.C. Co-ingestion of protein and leucine stimulates muscle protein synthesis rates to the same extent in young and elderly lean men. Am. J. Clin. Nutr. 2006, 84, 623-632. [CrossRef]

52. Paddon-Jones, D.; Sheffield-Moore, M.; Katsanos, C.S.; Zhang, X.J.; Wolfe, R.R. Differential stimulation of muscle protein synthesis in elderly humans following isocaloric ingestion of amino acids or whey protein. Exp. Gerontol. 2006, 41, 215-219. [CrossRef]

53. Paddon-Jones, D.; Sheffield-Moore, M.; Zhang, X.J.; Volpi, E.; Wolf, E.S.; Aarsland, A.; Ferrando, A.A.; Wolfe, R.R. Amino acid ingestion improves muscle protein synthesis in the young and elderly. Am. J. Physiol. Metab. 2004, 286, 321-328. [CrossRef] [PubMed]

54. Houston, D.K.; Nicklas, B.J.; Ding, J.; Harris, T.B.; Tylavsky, A.F.; Newman, A.B.; Lee, J.S.; Sahyoun, N.R.; Visser, M.; Kritchevsky, S.B.; et al. Dietary protein intake is associated with lean mass change in older, community-dwelling adults: The Health, Aging, and Body Composition (Health ABC) Study. Am. J. Clin. Nutr. 2008, 87, 150-155. [CrossRef] [PubMed]

55. Isanejad, M.; Mursu, J.; Sirola, J.; Kröger, H.; Rikkonen, T.; Tuppurainen, M.; Erkkilä, A.T. Dietary protein intake is associated with better physical function and muscle strength among elderly women. Br. J. Nutr. 2016, 115, 1281-1291. [CrossRef] [PubMed]

56. Landi, F.; Calvani, R.; Tosato, M.; Martone, A.M.; Picca, A.; Ortolani, E.; Savera, G.; Salini, S.; Ramaschi, M.; Bernabei, R.; et al. Animal-derived protein consumption is associated with muscle mass and strength in community-dwellers: Results from the Milan Expo survey. J. Nutr. Health Aging 2017, 21, 1050-1056. [CrossRef] [PubMed]

57. Tieland, M.; Van De Rest, O.; Dirks, M.L.; Van Der Zwaluw, N.; Mensink, M.; Van Loon, L.J.; De Groot, L.C. Protein Supplementation Improves Physical Performance in Frail Elderly People: A Randomized, Double-Blind, Placebo-Controlled Trial. J. Am. Med. Dir. Assoc. 2012, 13, 720-726. [CrossRef]

58. Trappe, T.A.; Burd, N.A.; Louis, E.S.; Lee, G.A.; Trappe, S.W. Influence of concurrent exercise or nutrition countermeasures on thigh and calf muscle size and function during 60 days of bed rest in women. Acta Physiol. 2007, 191, 147-159. [CrossRef] [PubMed]

59. Morley, J.E. Anorexia of aging: A true geriatric syndrome. J. Nutr. Health Aging 2012, 16, 422-425. [CrossRef]

60. Malafarina, V.; Uriz-Otano, F.; Gil-Guerrero, L.; Iniesta, R. The anorexia of ageing: Physiopathology, prevalence, associated comorbidity and mortality. A systematic review. Maturitas 2013, 74, 293-302. [CrossRef]

61. Drewnowski, A.; Shultz, J.M. Impact of aging on eating behaviors, food choices, nutrition, and health status. J. Nutr. Health Aging 2001, 5, 75-79.

62. Deutz, N.E.P.; Bauer, J.M.; Barazzoni, R.; Biolo, G.; Boirie, Y.; Bosy-Westphal, A.; Cederholm, T.; Cruz-Jentoft, A.J.; Krznaric, Z.; Nair, K.S.; et al. Protein intake and exercise for optimal muscle function with aging: Recommendations from the ESPEN Expert Group. Clin. Nutr. 2014, 33, 929-936. [CrossRef]

63. WHO/FAO/UNU. Protein and Amino Acid Requirements in Human Nutrition; Report of a Joint WHO/FAO/UNU Expert Consultation; WHO: Geneva, Switzerland, 2007.

64. Gray-Donald, K.; St-Arnaud-McKenzie, D.; Gaudreau, P.; Morais, J.A.; Shatenstein, B.; Payette, H. Protein intake protects against weight loss in healthy community-dwelling older adults. J. Nutr. 2014, 144, 321-326. [CrossRef] [PubMed]

65. Burd, N.A.; Gorissen, S.H.; Van Loon, L.J. Anabolic Resistance of Muscle Protein Synthesis with Aging. Exerc. Sport Sci. Rev. 2013, 41, 169-173. [CrossRef] [PubMed]

66. Koopman, R.; Walrand, S.; Beelen, M.; Gijsen, A.P.; Kies, A.K.; Boirie, Y.; Saris, W.H.M.; Van Loon, L.J.C. Dietary Protein Digestion and Absorption Rates and the Subsequent Postprandial Muscle Protein Synthetic Response Do Not Differ between Young and Elderly Men. J. Nutr. 2009, 139, 1707-1713. [CrossRef] [PubMed]

67. Walrand, S.; Guillet, C.; Salles, J.; Cano, N.; Boirie, Y. Physiopathological Mechanism of Sarcopenia. Clin. Geriatr. Med. 2011, 27, 365-385. [CrossRef] [PubMed] 
68. Gaffney-Stomberg, E.; Insogna, K.L.; Rodriguez, N.R.; Kerstetter, J.E. Increasing Dietary Protein Requirements in Elderly People for Optimal Muscle and Bone Health. J. Am. Geriatr. Soc. 2009, 57, 1073-1079. [CrossRef]

69. Surdykowski, A.K.; Kenny, A.M.; Insogna, K.L.; Kerstetter, E.J. Optimizing bone health in older adults: The importance of dietary protein. Aging Health 2010, 6, 345-357. [CrossRef] [PubMed]

70. Van Vliet, S.; Burd, A.N.; Van Loon, L.J. The Skeletal Muscle Anabolic Response to Plant- versus Animal-Based Protein Consumption. J. Nutr. 2015, 145, 1981-1991. [CrossRef]

71. Soop, M.; Nehra, V.; Henderson, G.C.; Boirie, Y.; Ford, G.C.; Nair, K.S. Coingestion of whey protein and casein in a mixed meal: Demonstration of a more sustained anabolic effect of casein. Am. J. Physiol. Metab. 2012, 303, E152-E162. [CrossRef]

72. Dangin, M.; Guillet, C.; Garcia-Rodenas, C.; Gachon, P.; Bouteloup-Demange, C.; Reiffers-Magnani, K.; Fauquant, J.; Ballevre, O.; Beaufrere, B. The rate of protein digestion affects protein gain differently during aging in humans. J. Physiol. 2003, 549, 635-644. [CrossRef]

73. Burd, N.A.; Yang, Y.; Moore, D.R.; Tang, J.E.; Tarnopolsky, M.A.; Phillips, S.M. Greater stimulation of myofibrillar protein synthesis with ingestion of whey protein isolate v. micellar casein at rest and after resistance exercise in elderly men. Br. J. Nutr. 2012, 108, 958-962. [CrossRef]

74. Paddon-Jones, D.; Van Loon, L.J. Nutritional Approaches to Treating Sarcopenia. In Sarcopenia; Wiley: Hoboken, NJ, USA, 2012; pp. 275-295.

75. Bouillanne, O.; Curis, E.; Hamon-Vilcot, B.; Nicolis, I.; Chretien, P.; Schauer, N.; Vincent, J.P.; Cynober, L.; Aussel, C. Impact of protein pulse feeding on lean mass in malnourished and at-risk hospitalized elderly patients: A randomized controlled trial. Clin. Nutr. 2013, 32, 186-192. [CrossRef] [PubMed]

76. Deutz, N.E.; Wolfe, R.R. Is there a maximal anabolic response to protein intake with a meal? Clin. Nutr. 2013, 32, 309-313. [CrossRef] [PubMed]

77. Lin, R.; Liu, W.; Piao, M.; Zhu, H. A review of the relationship between the gut microbiota and amino acid metabolism. Amino Acids 2017, 49, 2083-2090. [CrossRef] [PubMed]

78. Clark, A.; Mach, N. The Crosstalk between the Gut Microbiota and Mitochondria during Exercise. Front. Physiol. 2017, 8, 319. [CrossRef] [PubMed]

79. Ticinesi, A.; Lauretani, F.; Milani, C.; Nouvenne, A.; Tana, C.; Del Rio, D.; Maggio, M.; Ventura, M.; Meschi, T. Aging Gut Microbiota at the Cross-Road between Nutrition, Physical Frailty, and Sarcopenia: Is There a Gut-Muscle Axis? Nutrients 2017, 9, 1303. [CrossRef] [PubMed]

80. Wong, J.M.W.; De Souza, R.; Kendall, C.W.C.; Emam, A.; Jenkins, D.J.A. Colonic health: Fermentation and short chain fatty acids. J. Clin. Gastroenterol. 2006, 40, 235-243. [CrossRef] [PubMed]

81. Besten, G.D.; Lange, K.; Havinga, R.; Van Dijk, T.H.; Gerding, A.; Van Eunen, K.; Muller, M.; Groen, A.K.; Hooiveld, G.J.; Bakker, B.M.; et al. Gut-derived short-chain fatty acids are vividly assimilated into host carbohydrates and lipids. Am. J. Physiol. Liver Physiol. 2013, 305, G900-G910. [CrossRef] [PubMed]

82. Besten, G.D.; Van Eunen, K.; Groen, A.K.; Venema, K.; Reijngoud, D.J.; Bakker, B.M. The role of short-chain fatty acids in the interplay between diet, gut microbiota, and host energy metabolism. J. Lipid Res. 2013, 54, 2325-2340. [CrossRef] [PubMed]

83. Sonnenburg, J.L.; Bäckhed, F. Diet-microbiota interactions as moderators of human metabolism. Nature 2016, 535, 56-64. [CrossRef]

84. Shapiro, H.; Thaiss, A.C.; Levy, M.; Elinav, E. The cross talk between microbiota and the immune system: Metabolites take center stage. Curr. Opin. Immunol. 2014, 30, 54-62. [CrossRef]

85. Anthony, J.C.; Anthony, T.G.; Kimball, S.R.; Jefferson, L.S. Signaling pathways involved in translational control of protein synthesis in skeletal muscle by leucine. J. Nutr. 2011, 131, 856S-860S. [CrossRef] [PubMed]

86. Anthony, J.C.; Yoshizawa, F.; Anthony, T.G.; Jefferson, L.S.; Vary, T.C.; Kimball, S.R. Leucine Stimulates Translation Initiation in Skeletal Muscle of Postabsorptive Rats via a Rapamycin-Sensitive Pathway. J. Nutr. 2000, 130, 2413-2419. [CrossRef] [PubMed]

87. Nakashima, K.; Ishida, A.; Yamazaki, M.; Abé, H. Leucine suppresses myofibrillar proteolysis by down-regulating ubiquitin-proteasome pathway in chick skeletal muscles. Biochem. Biophys. Res. Commun. 2005, 336, 660-666. [CrossRef] [PubMed]

88. Katsanos, C.S.; Kobayashi, H.; Sheffield-Moore, M.; Aarsland, A.; Wolfe, R.R. Aging is associated with diminished accretion of muscle proteins after the ingestion of a small bolus of essential amino acids. Am. J. Clin. Nutr. 2005, 82, 1065-1073. [CrossRef] [PubMed] 
89. Xu, Z.; Tan, Z.; Zhang, Q.; Gui, Q.; Yang, Y. The effectiveness of leucine on muscle protein synthesis, lean body mass and leg lean mass accretion in older people: A systematic review and meta-analysis. Br. J. Nutr. 2015, 113, 25-34. [CrossRef] [PubMed]

90. McDonald, C.K.; Ankarfeldt, M.Z.; Capra, S.; Bauer, J.; Raymond, K.; Heitmann, B.L. Lean body mass change over 6 years is associated with dietary leucine intake in an older Danish population. Br. J. Nutr. 2016, 115, 1556-1562. [CrossRef] [PubMed]

91. Børsheim, E.; Bui, Q.-U.T.; Tissier, S.; Kobayashi, H.; Ferrando, A.A.; Wolfe, R.R. Effect of Amino Acid Supplementation on Muscle Mass, Strength and Physical Function in Elderly. Clin. Nutr. 2008, 27, 189-195. [CrossRef]

92. Gerlinger-Romero, F.; Guimarães-Ferreira, L.; Giannocco, G.; Nunes, M. Chronic supplementation of beta-hydroxy-beta methylbutyrate $(\mathrm{HM} \beta)$ increases the activity of the GH/IGF-I axis and induces hyperinsulinemia in rats. Growth Horm. IGF Res. 2011, 21, 57-62. [CrossRef]

93. Smith, H.J.; Mukerji, P.; Tisdale, M.J. Attenuation of proteasome-induced proteolysis in skeletal muscle by \{beta\}-hydroxy-\{beta\}-methylbutyrate in cancer-induced muscle loss. Cancer Res. 2005, 65, 277-283.

94. Smith, H.J.; Wyke, S.M.; Tisdale, M.J. Mechanism of the attenuation of proteolysis-inducing factor stimulated protein degradation in muscle by beta-hydroxy-beta-methylbutyrate. Cancer Res. 2004, 64, 8731-8735. [CrossRef]

95. HoleČek, M. Beta-hydroxy-beta-methylbutyrate supplementation and skeletal muscle in healthy and muscle-wasting conditions. J. Cachex Sarcopenia Muscle 2017, 8, 529-541. [CrossRef] [PubMed]

96. He, X.; Duan, Y.; Yao, K.; Li, F.; Hou, Y.; Wu, G.; Yin, Y. $\beta$-Hydroxy- $\beta$-methylbutyrate, mitochondrial biogenesis, and skeletal muscle health. Amino Acids 2016, 48, 653-664. [CrossRef] [PubMed]

97. Wilson, G.J.; Wilson, J.M.; Manninen, A.H. Effects of beta-hydroxy-beta-methylbutyrate (HMB) on exercise performance and body composition across varying levels of age, sex, and training experience: A review. Nutr. Metab. 2008, 5, 1. [CrossRef] [PubMed]

98. Kornasio, R.; Riederer, I.; Butler-Browne, G.; Mouly, V.; Uni, Z.; Halevy, O. $\beta$-hydroxy- $\beta$-methylbutyrate (HMB) stimulates myogenic cell proliferation, differentiation and survival via the MAPK/ERK and PI3K/Akt pathways. Biochim. Biophys. Acta Mol. Cell Res. 2009, 1793, 755-763. [CrossRef] [PubMed]

99. Van Koevering, M.; Nissen, S. Oxidation of leucine and alpha-ketoisocaproate to beta-hydroxy-beta-methylbutyrate in vivo. Am. J. Physiol. Metab. 1992, 262, 27-31. [CrossRef] [PubMed]

100. Kuriyan, R.; Lokesh, D.P.; Selvam, S.; Jayakumar, J.; Philip, M.G.; Shreeram, S.; Kurpad, A.V.; Sathyavageeswaran, $\mathrm{S}$. The relationship of endogenous plasma concentrations of $\beta$-Hydroxy $\beta$-Methyl Butyrate (HMB) to age and total appendicular lean mass in humans. Exp. Gerontol. 2016, 81, 13-18. [CrossRef] [PubMed]

101. Portal, S.; Eliakim, A.; Nemet, D.; Halevy, O.; Zadik, Z. Effect of HMB supplementation on body composition, fitness, hormonal profile and muscle damage indices. J. Pediatr. Endocrinol. Metab. 2010, 23, 641-650. [CrossRef]

102. Flakoll, P.; Sharp, R.; Baier, S.; Levenhagen, D.; Carr, C.; Nissen, S. Effect of beta-hydroxy-beta-methylbutyrate, arginine, and lysine supplementation on strength, functionality, body composition, and protein metabolism in elderly women. Nutrition 2004, 20, 445-451. [CrossRef]

103. Argilés, J.M.; Campos, N.; Lopez-Pedrosa, J.M.; Rueda, R.; Rodriguez-Mañas, L. Skeletal Muscle Regulates Metabolism via Interorgan Crosstalk: Roles in Health and Disease. J. Am. Med. Dir. Assoc. 2016, 17, 789-796. [CrossRef]

104. Deutz, N.E.; Pereira, S.L.; Hays, N.P.; Oliver, J.S.; Edens, N.K.; Evans, C.M.; Wolfe, R.R. Effect of $\beta$-hydroxy- $\beta$-methylbutyrate (HMB) on lean body mass during 10 days of bed rest in older adults. Clin. Nutr. 2013, 32, 704-712. [CrossRef]

105. Fitschen, P.J.; Wilson, G.J.; Wilson, J.M.; Wilund, K.R. Efficacy of $\beta$-hydroxy- $\beta$-methylbutyrate supplementation in elderly and clinical populations. Nutrition 2013, 29, 29-36. [CrossRef] [PubMed]

106. Cynober, L. Ornithine alpha-ketoglutarate as a potent precursor of arginine and nitric oxide: A new job for an old friend. J. Nutr. 2004, 134, 2858S-2862S. [CrossRef] [PubMed]

107. Walrand, S. Ornithine alpha-ketoglutarate: Could it be a new therapeutic option for sarcopenia? J. Nutr. Health Aging 2010, 14, 570-577. [CrossRef] [PubMed] 
108. Brocker, P.; Vellas, B.; Albarede, J.L.; Poynard, T. A Two-centre, Randomized, Double-blind Trial of Ornithine Oxoglutarate in 194 Elderly, Ambulatory, Convalescent Subjects. Age Ageing 1994, 23, 303-306. [CrossRef] [PubMed]

109. Segaud, F.; Combaret, L.; Neveux, N.; Attaix, D.; Cynober, L.; Moinard, C. Effects of ornithine alpha-ketoglutarate on protein metabolism in Yoshida sarcoma-bearing rats. Clin. Nutr. 2007, 26, 624-630. [CrossRef]

110. Donati, L.; Ziegler, F.; Pongelli, G.; Signorini, M.S. Nutritional and clinical efficacy of ornithine alpha-ketoglutarate in severe burn patients. Clin. Nutr. 1999, 18, 307-311. [CrossRef]

111. Wernerman, J.; Hammarqvist, F.; Von Der Decken, A.; Vinnars, E. Ornithine-alpha-ketoglutarate Improves Skeletal Muscle Protein Synthesis as Assessed by Ribosome Analysis and Nitrogen Use After Surgery. Ann. Surg. 1987, 208, 674-680. [CrossRef]

112. Visser, M.; Deeg, D.J.H.; Lips, P.; Longitudinal Aging Study Amsterdam. Low vitamin D and high parathyroid hormone levels as determinants of loss of muscle strength and muscle mass (sarcopenia): The Longitudinal Aging Study Amsterdam. J. Clin. Endocrinol. Metab. 2003, 88, 5766-5772. [CrossRef]

113. Scott, D.; Blizzard, L.; Fell, J.; Ding, C.; Winzenberg, T.; Jones, G. A prospective study of the associations between 25 -hydroxy-vitamin D, sarcopenia progression and physical activity in older adults. Clin. Endocrinol. 2010, 73, 581-587. [CrossRef]

114. Johnson, M.A.; Kimlin, M.G. Vitamin D, Aging, and the 2005 Dietary Guidelines for Americans. Nutr. Rev. 2006, 64, 410-421. [CrossRef]

115. Borchers, M.; Gudat, F.; Dürmüller, U.; Stahelin, H.; Dick, W.; Bischoff-Ferrari, H.; Bischoff-Ferrari, H. Vitamin D Receptor Expression in Human Muscle Tissue Decreases With Age. J. Bone Miner. Res. 2004, 19, 265-269.

116. Ceglia, L.; Morais, M.D.S.; Park, L.K.; Morris, E.; Harris, S.S.; Bischoff-Ferrari, H.A.; Fielding, R.A.; Dawson-Hughes, B. Multi-step immunofluorescent analysis of vitamin D receptor loci and myosin heavy chain isoforms in human skeletal muscle. J. Mol. Histol. 2010, 41, 137-142. [CrossRef] [PubMed]

117. Ceglia, L. Vitamin D and skeletal muscle tissue and function. Mol. Asp. Med. 2008, 29, 407-414. [CrossRef] [PubMed]

118. Montero-Odasso, M.; Duque, G. Vitamin D in the aging musculoskeletal system: An authentic strength preserving hormone. Mol. Asp. Med. 2005, 26, 203-219. [CrossRef] [PubMed]

119. Pojednic, R.M.; Ceglia, L.; Olsson, K.; Gustafsson, T.; Lichtenstein, A.H.; Dawson-Hughes, B.; Fielding, R.A. Effects of 1, 25-dihydroxyvitamin D3 and vitamin D3 on the expression of the vitamin d receptor in human skeletal muscle cells. Calcif. Tissue Int. 2015, 96, 256-263. [CrossRef]

120. Muir, S.W.; Montero-Odasso, M.; Montero-Odasso, M.; Montero-Odasso, M. Effect of Vitamin D Supplementation on Muscle Strength, Gait and Balance in Older Adults: A Systematic Review and Meta-Analysis. J. Am. Geriatr. Soc. 2011, 59, 2291-2300. [CrossRef]

121. Beaudart, C.; Buckinx, F.; Rabenda, V.; Gillain, S.; Cavalier, E.; Slomian, J.; Petermans, J.; Reginster, J.Y.; Bruyère, $\mathrm{O}$. The Effects of Vitamin D on Skeletal Muscle Strength, Muscle Mass, and Muscle Power: A Systematic Review and Meta-Analysis of Randomized Controlled Trials. J. Clin. Endocrinol. Metab. 2014, 99, 4336-4345. [CrossRef]

122. Yamada, M.; Arai, H.; Yoshimura, K.; Kajiwara, Y.; Sonoda, T.; Nishiguchi, S.; Aoyama, T. Nutritional Supplementation during Resistance Training Improved Skeletal Muscle Mass in Community-Dwelling Frail Older Adults. J. Frailty Aging 2012, 1, 64-70.

123. Kurosawa, Y.; Hamaoka, T.; Katsumura, T.; Kuwamori, M.; Kimura, N.; Sako, T.; Chance, B. Creatine supplementation enhances anaerobic ATP synthesis during a single $10 \mathrm{sec}$ maximal handgrip exercise. Guanidino Compd. Biol. Med. 2003, 244, 105-112.

124. Bemben, M.G.; Lamont, H.S. Creatine supplementation and exercise performance: Recent findings. Sports Med. 2005, 35, 107-125. [CrossRef]

125. Ingwall, J.S. Creatine and the control of muscle-specific protein synthesis in cardiac and skeletal muscle. Circ. Res. 1976, 38, 115-123.

126. Lang, F.; Busch, G.L.; Ritter, M.; Völkl, H.; Waldegger, S.; Gulbins, E.; Häussinger, D. Functional Significance of Cell Volume Regulatory Mechanisms. Physiol. Rev. 1998, 78, 247-306. [CrossRef] [PubMed]

127. Burke, D.G.; Candow, D.G.; Chilibeck, P.D.; MacNeil, L.G.; Roy, B.D.; Tarnopolsky, M.A.; Ziegenfuss, T. Effect of creatine supplementation and resistance-exercise training on muscle insulin-like growth factor in young adults. Int. J. Sport Nutr. Exerc. Metab. 2008, 18, 389-398. [CrossRef] [PubMed] 
128. Louis, M.; Van Beneden, R.; Dehoux, M.; Thissen, J.P.; Francaux, M. Creatine increases IGF-I and myogenic regulatory factor mRNA in C(2)C(12) cells. FEBS Lett. 2004, 557, 243-247. [CrossRef]

129. Deldicque, L.; Louis, M.; Theisen, D.; Nielens, H.; Dehoux, M.; Thissen, J.P.; Rennie, M.J.; Francaux, M. Increased IGF mRNA in Human Skeletal Muscle after Creatine Supplementation. Med. Sci. Sports Exerc. 2005, 37, 731-736. [CrossRef]

130. Deldicque, L.; Theisen, D.; Bertrand, L.; Hespel, P.; Hue, L.; Francaux, M. Creatine enhances differentiation of myogenic $\mathrm{C}(2) \mathrm{C}(12)$ cells by activating both $\mathrm{p} 38$ and $\mathrm{Akt} / \mathrm{PKB}$ pathways. Am. J. Physiol. Physiol. 2007, 293, C1263-C1271. [CrossRef] [PubMed]

131. Fujita, S.; Dreyer, H.C.; Drummond, M.J.; Glynn, E.L.; Cadenas, J.G.; Yoshizawa, F.; Volpi, E.; Rasmussen, B.B. Nutrient signalling in the regulation of human muscle protein synthesis. J. Physiol. 2007, 582, 813-823. [CrossRef]

132. Bentzinger, C.F.; Lin, S.; Romanino, K.; Castets, P.; Guridi, M.; Summermatter, S.; Handschin, C.; Tintignac, A.L.; Hall, M.N.; Ruegg, A.M. Differential response of skeletal muscles to mTORC1 signaling during atrophy and hypertrophy. Skelet. Muscle 2013, 3, 6. [CrossRef]

133. Bentzinger, C.F.; Romanino, K.; Cloëtta, D.; Lin, S.; Mascarenhas, J.B.; Oliveri, F.; Xia, J.; Casanova, E.; Costa, C.F.; Brink, M.; et al. Skeletal Muscle-Specific Ablation of raptor, but Not of rictor, Causes Metabolic Changes and Results in Muscle Dystrophy. Cell Metab. 2008, 8, 411-424. [CrossRef]

134. Zanou, N.; Gailly, P. Skeletal muscle hypertrophy and regeneration: Interplay between the myogenic regulatory factors (MRFs) and insulin-like growth factors (IGFs) pathways. Cell. Mol. Life Sci. 2013, 70, 4117-4130. [CrossRef]

135. Deldicque, L.; Theisen, D.; Francaux, M. Regulation of mTOR by amino acids and resistance exercise in skeletal muscle. Graefe's Arch. Clin. Exp. Ophthalmol. 2005, 94, 1-10. [CrossRef] [PubMed]

136. Kirwan, J.P.; Del Aguila, L.F.; Hernandez, J.M.; Williamson, D.L.; O'Gorman, D.J.; Lewis, R.; Krishnan, R.K. Regular exercise enhances insulin activation of IRS-1-associated PI3-kinase in human skeletal muscle. J. Appl. Physiol. 2000, 88, 797-803. [CrossRef] [PubMed]

137. Willoughby, D.S.; McFarlin, B.; Bois, C. Interleukin-6 Expression after Repeated Bouts of Eccentric Exercise. Int. J. Sports Med. 2003, 24, 15-21. [CrossRef] [PubMed]

138. Ferretti, R.; Moura, E.G.; Dos Santos, V.C.; Caldeira, E.J.; Conte, M.; Matsumura, C.Y.; Pertille, A.; Mosqueira, M. High-fat diet suppresses the positive effect of creatine supplementation on skeletal muscle function by reducing protein expression of IGF-PI3K-AKT-mTOR pathway. PLoS ONE 2018, 13, e0199728. [CrossRef] [PubMed]

139. Möller, P.; Bergström, J.; Fürst, P.; Hellström, K. Effect of aging on energy-rich phosphagens in human skeletal muscles. Clin. Sci. 1980, 58, 553-555. [CrossRef] [PubMed]

140. Candow, D.G. Sarcopenia: Current theories and the potential beneficial effect of creatine application strategies. Biogerontology 2011, 12, 273-281. [CrossRef]

141. Liguori, I.; Russo, G.; Curcio, F.; Bulli, G.; Aran, L.; Della-Morte, D.; Gargiulo, G.; Testa, G.; Cacciatore, F.; Bonaduce, D.; et al. Oxidative stress, aging, and diseases. Clin. Interv. Aging 2018, 13, 757-772. [CrossRef]

142. Yakes, F.M.; Van Houten, B. Mitochondrial DNA damage is more extensive and persists longer than nuclear DNA damage in human cells following oxidative stress. Proc. Natl. Acad. Sci. USA 1997, 94, 514-519. [CrossRef]

143. Marzetti, E.; Calvani, R.; Cesari, M.; Buford, T.W.; Lorenzi, M.; Behnke, B.J.; Leeuwenburgh, C. Mitochondrial dysfunction and sarcopenia of aging: From signaling pathways to clinical trials. Int. J. Biochem. Cell Biol. 2013, 45, 2288-2301. [CrossRef]

144. Howl, J.D.; Publicover, S.J. Permeabilisation of the sarcolemma in mouse diaphragm exposed to Bay $\mathrm{K} 8644$ in vitro: Time course, dependence on Ca2+ and effects of enzyme inhibitors. Acta Neuropathol. 1990, 79, 438-443. [CrossRef]

145. Kim, J.S.; Wilson, J.M.; Lee, S.R. Dietary implications on mechanisms of sarcopenia: Roles of protein, amino acids and antioxidants. J. Nutr. Biochem. 2010, 21, 1-13. [CrossRef] [PubMed]

146. Lauretani, F.; Semba, R.D.; Bandinelli, S.; Dayhoff-Brannigan, M.; Lauretani, F.; Corsi, A.M.; Guralnik, J.M.; Ferrucci, L. Carotenoids as Protection Against Disability in Older Persons. Rejuvenation Res. 2008, 11, 557-563. [CrossRef] [PubMed] 
147. Lauretani, F.; Semba, R.D.; Bandinelli, S.; Dayhoff-Brannigan, M.; Giacomini, V.; Corsi, A.M.; Guralnik, J.M.; Ferrucci, L. Low Plasma Carotenoids and Skeletal Muscle Strength Decline Over 6 Years. J. Gerontol. Ser. A Biol. Sci. Med Sci. 2008, 63, 376-383. [CrossRef] [PubMed]

148. Bjørnsen, T.; Salvesen, S.; Berntsen, S.; Hetlelid, K.J.; Stea, T.H.; Lohne-Seiler, H.; Rohde, G.; Haraldstad, K.; Raastad, T.; Køpp, U.; et al. Vitamin C and E supplementation blunts increases in total lean body mass in elderly men after strength training. Scand. J. Med. Sci. Sports 2016, 26, 755-763. [CrossRef] [PubMed]

149. Handy, D.E.; Loscalzo, J. Redox Regulation of Mitochondrial Function. Antioxid. Redox Signal. 2012, 16, 1323-1367. [CrossRef] [PubMed]

150. Ji, L.L. Antioxidant signaling in skeletal muscle: A brief review. Exp. Gerontol. 2007, 42, 582-593. [CrossRef]

151. Musarò, A.; Fulle, S.; Fano, G. Oxidative stress and muscle homeostasis. Curr. Opin. Clin. Nutr. Metab. Care 2010, 13, 236-242. [CrossRef] [PubMed]

152. Gutteridge, J.M.; Halliwell, B. Antioxidants: Molecules, medicines, and myths. Biochem. Biophys. Res. Commun. 2010, 393, 561-564. [CrossRef] [PubMed]

153. Ristow, M.; Zarse, K.; Oberbach, A.; Klöting, N.; Birringer, M.; Kiehntopf, M.; Stumvoll, M.; Kahn, C.R.; Blüher, M. Antioxidants prevent health-promoting effects of physical exercise in humans. Proc. Natl. Acad. Sci. USA 2009, 106, 8665-8670. [CrossRef]

154. Miller, E.; Pastor-Barriuso, R.; Dalal, D.; Riemersma, R.; Appel, L.; Guallar, E. Meta-Analysis: High-Dosage Vitamin E Supplementation May Increase All-Cause Mortality. ACC Curr. J. Rev. 2005, 14, 17. [CrossRef]

155. Bjelakovic, G.; Nikolova, D.; Gluud, L.L.; Simonetti, R.G.; Gluud, C. Mortality in Randomized Trials of Antioxidant Supplements for Primary and Secondary Prevention: Systematic Review and Meta-analysis. JAMA 2007, 297, 842. [CrossRef] [PubMed]

156. Bjelaković, G.; Nikolova, D.; Gluud, L.L.; Simonetti, R.G.; Gluud, C. Antioxidant supplements for prevention of mortality in healthy participants and patients with various diseases. Cochrane Database Syst. Rev. 2012. [CrossRef] [PubMed]

157. Fusco, D.; Colloca, G.; Monaco, M.R.L.; Cesari, M. Effects of antioxidant supplementation on the aging process. Clin. Interv. Aging 2007, 2, 377-387. [PubMed]

158. Bouayed, J.; Bohn, T. Exogenous antioxidants-Double-edged swords in cellular redox state: Health beneficial effects at physiologic doses versus deleterious effects at high doses. Oxid. Med. Cell. Longev. 2010, 3, $228-237$. [CrossRef] [PubMed]

159. Smith, G.I. The Effects of Dietary Omega-3s on Muscle Composition and Quality in Older Adults. Curr. Nutr. Rep. 2016, 5, 99-105. [CrossRef] [PubMed]

160. Li, K.; Huang, T.; Zheng, J.; Wu, K.; Li, D. Effect of Marine-Derived n-3 Polyunsaturated Fatty Acids on C-Reactive Protein, Interleukin 6 and Tumor Necrosis Factor $\alpha$ : A Meta-Analysis. PLoS ONE 2014, 9, e88103. [CrossRef] [PubMed]

161. Calder, P.C. n-3 polyunsaturated fatty acids, inflammation, and inflammatory diseases. Am. J. Clin. Nutr. 2006, 83, 1505S-1519S. [CrossRef]

162. Welch, A.A.; MacGregor, A.J.; Minihane, A.-M.; Skinner, J.; Valdes, A.A.; Spector, T.D.; Cassidy, A. Dietary Fat and Fatty Acid Profile Are Associated with Indices of Skeletal Muscle Mass in Women Aged 18-79 Years. J. Nutr. 2014, 144, 327-334. [CrossRef]

163. Robinson, S.M.; Jameson, K.A.; Batelaan, S.F.; Martin, H.J.; Syddall, H.E.; Dennison, E.M.; Cooper, C.; Sayer, A.A.; Hertfordshire Cohort Study Group. Diet and its relationship with grip strength in community-dwelling older men and women: The Hertfordshire cohort study. J. Am. Geriatr. Soc. 2008, 56, 84-90. [CrossRef]

164. Hutchins-Wiese, H.L.; Kleppinger, A.; Annis, K.; Liva, E.; Lammi-Keefe, C.J.; Durham, H.A.; Kenny, A.M. The impact of supplemental n-3 long chain polyunsaturated fatty acids and dietary antioxidants on physical performance in postmenopausal women. J. Nutr. Health Aging 2013, 17, 76-80. [CrossRef]

165. Krzymińska-Siemaszko, R.; Czepulis, N.; Lewandowicz, M.; Zasadzka, E.; Suwalska, A.; Witowski, J.; Wieczorowska-Tobis, K. The Effect of a 12-Week Omega-3 Supplementation on Body Composition, Muscle Strength and Physical Performance in Elderly Individuals with Decreased Muscle Mass. Int. J. Environ. Res. Public Health 2015, 12, 10558-10574. [CrossRef] [PubMed]

166. Jäger, S.; Trojan, H.; Kopp, T.; Laszczyk, M.N.; Scheffler, A. Pentacyclic Triterpene Distribution in Various Plants - Rich Sources for a New Group of Multi-Potent Plant Extracts. Molecules 2009, 14, 2016-2031. [CrossRef] [PubMed] 
167. Kunkel, S.D.; Suneja, M.; Ebert, S.M.; Bongers, K.S.; Fox, D.K.; Malmberg, S.E.; Alipour, F.; Shields, R.K.; Adams, C.M. mRNA Expression Signatures of Human Skeletal Muscle Atrophy Identify a Natural Compound that Increases Muscle Mass. Cell Metab. 2011, 13, 627-638. [CrossRef] [PubMed]

168. Lundberg, J.O. Nitrate transport in salivary glands with implications for NO homeostasis. Proc. Natl. Acad. Sci. USA 2012, 109, 13144-13145. [CrossRef] [PubMed]

169. Buford, T.W.; Anton, S.D.; Judge, A.R.; Marzetti, E.; Wohlgemuth, S.E.; Carter, C.S.; Leeuwenburgh, C.; Pahor, M.; Manini, T.M. Models of Accelerated Sarcopenia: Critical Pieces for Solving the Puzzle of Age-Related Muscle Atrophy. Ageing Res. Rev. 2010, 9, 369-383. [CrossRef] [PubMed]

170. Larsen, F.J.; Weitzberg, E.; Lundberg, J.O.; Ekblom, B. Dietary nitrate reduces maximal oxygen consumption while maintaining work performance in maximal exercise. Free Radic. Biol. Med. 2010, 48, 342-347. [CrossRef] [PubMed]

171. Larsen, F.J.; Schiffer, T.A.; Borniquel, S.; Sahlin, K.; Ekblom, B.; Lundberg, J.O.; Weitzberg, E. Dietary Inorganic Nitrate Improves Mitochondrial Efficiency in Humans. Cell Metab. 2011, 13, 149-159. [CrossRef]

172. Siervo, M.; Oggioni, C.; Jakovljevic, D.G.; Trenell, M.; Mathers, J.C.; Houghton, D.; Celis-Morales, C.; Ashor, A.W.; Ruddock, A.; Ranchordas, M.; et al. Dietary nitrate does not affect physical activity or outcomes in healthy older adults in a randomized, cross-over trial. Nutr. Res. 2016, 36, 1361-1369. [CrossRef]

173. Jones, A.M. Dietary Nitrate Supplementation and Exercise Performance. Sports Med. 2014, 44, 35-45. [CrossRef]

174. Grosicki, G.J.; Fielding, R.A.; Lustgarten, M.S. Gut Microbiota Contribute to Age-Related Changes in Skeletal Muscle Size, Composition, and Function: Biological Basis for a Gut-Muscle Axis. Calcif. Tissue Int. 2018, 102, 433-442. [CrossRef]

175. Picca, A.; Fanelli, F.; Calvani, R.; Mulé, G.; Pesce, V.; Sisto, A.; Pantanelli, C.; Bernabei, R.; Landi, F.; Marzetti, E. Gut Dysbiosis and Muscle Aging: Searching for Novel Targets against Sarcopenia. Mediat. Inflamm. 2018, 2018, 1-15. [CrossRef] [PubMed]

176. Rampelli, S.; Candela, M.; Turroni, S.; Biagi, E.; Collino, S.; Franceschi, C.; O’Toole, P.W.; Brigidi, P. Functional metagenomic profiling of intestinal microbiome in extreme ageing. Aging 2013, 5, 902-912. [CrossRef] [PubMed]

177. Steves, C.J.; Bird, S.; Williams, F.M.K.; Spector, T.D. The Microbiome and Musculoskeletal Conditions of Aging: A Review of Evidence for Impact and Potential Therapeutics. J. Bone Miner. Res. 2016, 31, 261-269. [CrossRef] [PubMed]

178. Quigley, E.M.M. Commentary: Synbiotics and gut microbiota in older people-A microbial guide to healthy ageing. Aliment. Pharmacol. Ther. 2013, 38, 1141-1142. [CrossRef] [PubMed]

179. Caputi, V.; Marsilio, I.; Filpa, V.; Cerantola, S.; Orso, G.; Bistoletti, M.; Paccagnella, N.; De Martin, S.; Montopoli, M.; Dall'Acqua, S.; et al. Antibiotic-induced dysbiosis of the microbiota impairs gut neuromuscular function in juvenile mice. Br. J. Pharmacol. 2017, 174, 3623-3639. [CrossRef] [PubMed]

180. De Vrese, M.; Schrezenmeir, J. Probiotics, Prebiotics, and Synbiotics. Adv. Biochem. Eng. Biotechnol. 2008, 111, 1-66. [PubMed]

181. Buigues, C.; Fernández-Garrido, J.; Pruimboom, L.; Hoogland, A.J.; Navarro-Martínez, R.; Martínez-Martínez, M.; Verdejo, Y.; Mascarós, M.C.; Peris, C.; Cauli, O. Effect of a Prebiotic Formulation on Frailty Syndrome: A Randomized, Double-Blind Clinical Trial. Int. J. Mol. Sci. 2016, 17, 932. [CrossRef] [PubMed]

182. Food and Agriculture Organization of the United Nations; World Health Organization. Probiotics in food: Health and Nutritional Properties and Guidelines for Evaluation; Food and Agriculture Organization of the United Nations; World Health Organization: Geneva, Switzerland, 2006.

183. Rondanelli, M.; Giacosa, A.; Faliva, M.A.; Perna, S.; Allieri, F.; Castellazzi, A.M. Review on microbiota and effectiveness of probiotics use in older. World J. Clin. Cases 2015, 3, 156-162. [CrossRef]

184. Varian, B.J.; Goureshetti, S.; Poutahidis, T.; Lakritz, J.R.; Levkovich, T.; Kwok, C.; Teliousis, K.; Ibrahim, Y.M.; Mirabal, S.; Erdman, S.E. Beneficial bacteria inhibit cachexia. Oncotarget 2016, 7, 11803-11816. [CrossRef]

185. Munukka, E.; Rintala, A.; Toivonen, R.; Nylund, M.; Yang, B.; Takanen, A.; Hänninen, A.; Vuopio, J.; Huovinen, P.; Jalkanen, S.; et al. Faecalibacterium prausnitzii treatment improves hepatic health and reduces adipose tissue inflammation in high-fat fed mice. ISME J. 2017, 11, 1667-1679. [CrossRef] 
186. Neyrinck, A.M.; Taminiau, B.; Walgrave, H.; Daube, G.; Cani, P.D.; Bindels, L.B.; Delzenne, N.M. Spirulina Protects against Hepatic Inflammation in Aging: An Effect Related to the Modulation of the Gut Microbiota? Nutrients 2017, 9, 633. [CrossRef] [PubMed]

187. Tiihonen, K.; Ouwehand, A.C.; Rautonen, N. Human intestinal microbiota and healthy ageing. Ageing Res. Rev. 2010, 9, 107-116. [CrossRef] [PubMed]

188. Singh, R.K.; Chang, H.W.; Yan, D.; Lee, K.M.; Ucmak, D.; Wong, K.; Abrouk, M.; Farahnik, B.; Nakamura, M.; Zhu, T.H.; et al. Influence of diet on the gut microbiome and implications for human health. J. Transl. Med. 2017, 15, 1101. [CrossRef] [PubMed]

189. Dickinson, J.M.; Volpi, E.; Rasmussen, B.B. Exercise and nutrition to target protein synthesis impairments in aging skeletal muscle. Exerc. Sport Sci. Rev. 2013, 41, 216-223. [CrossRef] [PubMed]

190. Glover, E.I.; Phillips, S.M.; Oates, B.R.; Tang, J.E.; Tarnopolsky, M.A.; Selby, A.; Smith, K.; Rennie, M.J. Immobilization induces anabolic resistance in human myofibrillar protein synthesis with low and high dose amino acid infusion. J. Physiol. 2008, 586, 6049-6061. [CrossRef] [PubMed]

191. WHO. Global Recommendations on Physical Activity for Health; WHO: Geneva, Switzerland, 2010.

192. Beckwée, D.; Delaere, A.; Aelbrecht, S.; Baert, V.; Beaudart, C.; Bruyere, O.; de Saint-Hubert, M.; Bautmans, I. Exercise Interventions for the Prevention and Treatment of Sarcopenia. A Systematic Umbrella Review. J. Nutr. Health Aging 2019, 23, 494-502. [CrossRef]

193. Azzolino, D.; Damanti, S.; Bertagnoli, L.; Lucchi, T.; Cesari, M. Sarcopenia and swallowing disorders in older people. Aging Clin. Exp. Res. 2019, 31,1-7. [CrossRef]

194. Bernardelli, G.; Roncaglione, C.; Damanti, S.; Mari, D.; Cesari, M.; Marcucci, M. Adapted physical activity to promote active and healthy ageing: The PoliFIT pilot randomized waiting list-controlled trial. Aging Clin. Exp. Res. 2019, 31, 511-518. [CrossRef]

195. So, C.; Pierluissi, E. Attitudes and Expectations Regarding Exercise in the Hospital of Hospitalized Older Adults: A Qualitative Study. J. Am. Geriatr. Soc. 2012, 60, 713-718. [CrossRef]

196. West, D.W.D.; Moore, D.R.; Staples, A.W.; Prior, T.; Tang, J.E.; Rennie, M.J.; Burd, N.A.; Atherton, P.J.; Baker, S.K.; Phillips, S.M. Enhanced Amino Acid Sensitivity of Myofibrillar Protein Synthesis Persists for up to $24 \mathrm{~h}$ after Resistance Exercise in Young Men. J. Nutr. 2011, 141, 568-573.

197. Yang, Y.; Breen, L.; Burd, N.A.; Hector, A.J.; Churchward-Venne, T.A.; Josse, A.R.; Tarnopolsky, M.A.; Phillips, S.M. Resistance exercise enhances myofibrillar protein synthesis with graded intakes of whey protein in older men. Br. J. Nutr. 2012, 108, 1780-1788. [CrossRef] [PubMed]

198. Conn, V.S.; Minor, M.A.; Burks, K.J.; Rantz, M.J.; Pomeroy, S.H. Integrative Review of Physical Activity Intervention Research with Aging Adults. J. Am. Geriatr. Soc. 2003, 51, 1159-1168. [CrossRef] [PubMed]

199. Kruger, J.; Buchner, D.M.; Prohaska, T.R. The Prescribed Amount of Physical Activity in Randomized Clinical Trials in Older Adults. Gerontologist 2009, 49, S100-S107. [CrossRef] [PubMed]

200. Fielding, A.R. Effects of exercise training in the elderly: Impact of progressive-resistance training on skeletal muscle and whole-body protein metabolism. Proc. Nutr. Soc. 1995, 54, 665-675. [CrossRef] [PubMed]

201. Van Abbema, R.; De Greef, M.; Crajé, C.; Krijnen, W.; Hobbelen, H.; Van Der Schans, C. What type, or combination of exercise can improve preferred gait speed in older adults? A meta-analysis. BMC Geriatr. 2015, 15, 2211. [CrossRef] [PubMed]

202. Hortobagyi, T.; Lesinski, M.; Gäbler, M.; VanSwearingen, J.M.; Malatesta, D.; Granacher, U. Effects of Three Types of Exercise Interventions on Healthy Old Adults' Gait Speed: A Systematic Review and Meta-Analysis. Sports Med. 2015, 45, 1627-1643. [CrossRef] [PubMed]

203. Peterson, M.D.; Sen, A.; Gordon, P.M. Influence of Resistance Exercise on Lean Body Mass in Aging Adults: A Meta-Analysis. Med. Sci. Sports Exerc. 2011, 43, 249-258. [CrossRef]

204. Borde, R.; Hortobágyi, T.; Granacher, U. Dose-Response Relationships of Resistance Training in Healthy Old Adults: A Systematic Review and Meta-Analysis. Sports Med. 2015, 45, 1693-1720. [CrossRef]

205. Fiatarone, M.A.; Marks, E.C.; Ryan, N.D.; Meredith, C.N.; Lipsitz, L.A.; Evans, W.J. High-Intensity Strength Training in Nonagenarians. JAMA 1990, 263, 3029. [CrossRef]

206. Fiatarone, M.A.; O’Neill, E.F.; Ryan, N.D.; Clements, K.M.; Solares, G.R.; Nelson, M.E.; Kehayias, J.J.; Lipsitz, L.A.; Roberts, S.B.; Evans, W.J. Exercise Training and Nutritional Supplementation for Physical Frailty in Very Elderly People. N. Engl. J. Med. 1994, 330, 1769-1775. [CrossRef] 
207. Serra-Rexach, J.A.; Bustamante-Ara, N.; Villarán, M.H.; Gil, P.G.; Ibáñez, M.J.S.; Sanz, N.B.; Santamaría, V.O.; Sanz, N.G.; Prada, A.B.M.; Gallardo, C.; et al. Short-Term, Light- to Moderate-Intensity Exercise Training Improves Leg Muscle Strength in the Oldest Old: A Randomized Controlled Trial. J. Am. Geriatr. Soc. 2011, 59, 594-602. [CrossRef] [PubMed]

208. Oettle, G.J. Effect of moderate exercise on bowel habit. Gut 1991, 32, 941-944. [CrossRef] [PubMed]

209. Vandeputte, D.; Falony, G.; Vieira-Silva, S.; Tito, R.Y.; Joossens, M.; Raes, J. Stool consistency is strongly associated with gut microbiota richness and composition, enterotypes and bacterial growth rates. Gut 2016, 65, 57-62. [CrossRef] [PubMed]

210. Zhu, L.; Liu, W.; Alkhouri, R.; Baker, R.D.; Bard, J.E.; Quigley, E.M.; Baker, S.S. Structural changes in the gut microbiome of constipated patients. Physiol. Genom. 2014, 46, 679-686. [CrossRef] [PubMed]

211. Tang, E.J.; Phillips, S.M. Maximizing muscle protein anabolism: The role of protein quality. Curr. Opin. Clin. Nutr. Metab. Care 2009, 12, 66-71. [CrossRef] [PubMed]

212. Shad, B.J.; Thompson, J.L.; Breen, L. Does the muscle protein synthetic response to exercise and amino acid-based nutrition diminish with advancing age? A systematic review. Am. J. Physiol. Metab. 2016, 311, E803-E817. [CrossRef]

213. Pennings, B.; Koopman, R.; Beelen, M.; Senden, J.M.; Saris, W.H.; van Loon, L.J. Exercising before protein intake allows for greater use of dietary protein-derived amino acids for de novo muscle protein synthesis in both young and elderly men. Am. J. Clin. Nutr. 2011, 93, 322-331. [CrossRef] [PubMed]

214. Yang, Y.; Churchward-Venne, A.T.; Burd, A.N.; Breen, L.; Tarnopolsky, A.M.; Phillips, S.M. Myofibrillar protein synthesis following ingestion of soy protein isolate at rest and after resistance exercise in elderly men. Nutr. Metab. 2012, 9, 57. [CrossRef]

215. Timmerman, K.L.; Dhanani, S.; Glynn, E.L.; Fry, C.S.; Drummond, M.J.; Jennings, K.; Rasmussen, B.B.; Volpi, E. A moderate acute increase in physical activity enhances nutritive flow and the muscle protein anabolic response to mixed nutrient intake in older adults123. Am. J. Clin. Nutr. 2012, 95, 1403-1412. [CrossRef]

216. Fujita, S.; Rasmussen, B.B.; Cadenas, J.G.; Drummond, M.J.; Glynn, E.L.; Sattler, F.R.; Volpi, E. Aerobic Exercise Overcomes the Age-Related Insulin Resistance of Muscle Protein Metabolism by Improving Endothelial Function and Akt/Mammalian Target of Rapamycin Signaling. Diabetes 2007, 56, 1615-1622. [CrossRef]

217. Cermak, N.M.; Res, P.T.; De Groot, L.C.; Saris, W.H.; Van Loon, L.J. Protein supplementation augments the adaptive response of skeletal muscle to resistance-type exercise training: A meta-analysis. Am. J. Clin. Nutr. 2012, 96, 1454-1464. [CrossRef] [PubMed]

218. Beaudart, C.; Dawson, A.; Shaw, S.C.; Harvey, N.C.; Kanis, J.A.; Binkley, N.; Reginster, J.Y.; Chapurlat, R.; Chan, D.C.; Bruyere, O.; et al. Nutrition and physical activity in the prevention and treatment of sarcopenia: Systematic review. Osteoporos. Int. 2017, 28, 1817-1833. [CrossRef] [PubMed]

219. Wilson, J.M.; Fitschen, P.J.; Campbell, B.; Wilson, G.J.; Zanchi, N.; Taylor, L.; Wilborn, C.; Kalman, D.S.; Stout, J.R.; Hoffman, J.R.; et al. International Society of Sports Nutrition Position Stand: Beta-hydroxy-beta-methylbutyrate (HMB). J. Int. Soc. Sports Nutr. 2013, 10, 6. [CrossRef] [PubMed]

220. Vukovich, M.D.; Stubbs, N.B.; Bohlken, R.M. Body composition in 70-year-old adults responds to dietary beta-hydroxy-beta-methylbutyrate similarly to that of young adults. J. Nutr. 2001, 131, 2049-2052. [CrossRef] [PubMed]

221. Silva, V.R.; Belozo, F.L.; Micheletti, T.O.; Conrado, M.; Stout, J.R.; Pimentel, G.D.; Gonzalez, A.M. $\beta$-hydroxy- $\beta$-methylbutyrate free acid supplementation may improve recovery and muscle adaptations after resistance training: A systematic review. Nutr. Res. 2017, 45, 1-9. [CrossRef] [PubMed]

222. Paddon-Jones, D.; Keech, A.; Jenkins, D. Short-term beta-hydroxy-beta-methylbutyrate supplementation does not reduce symptoms of eccentric muscle damage. Int. J. Sport Nutr. Exerc. Metab. 2001, 11, 442-450. [CrossRef] [PubMed]

223. Schiaffino, S.; Mammucari, C. Regulation of skeletal muscle growth by the IGF1-Akt/PKB pathway: Insights from genetic models. Skelet. Muscle 2011, 1, 4. [CrossRef] [PubMed]

224. Candow, D.G.; Chilibeck, P.D.; Chad, K.E.; Chrusch, M.J.; Davison, K.S.; Burke, D.G. Effect of Ceasing Creatine Supplementation while Maintaining Resistance Training in Older Men. J. Aging Phys. Act. 2004, 12, $219-231$. [CrossRef] [PubMed]

225. Becque, M.D.; Lochmann, J.D.; Melrose, D.R. Effects of oral creatine supplementation on muscular strength and body composition. Med. Sci. Sports Exerc. 2000, 32, 654-658. [CrossRef] [PubMed] 
226. Vandenberghe, K.; Goris, M.; Van Hecke, P.; Van Leemputte, M.; Vangerven, L.; Hespel, P. Long-term creatine intake is beneficial to muscle performance during resistance training. J. Appl. Physiol. 1997, 83, 2055-2063. [CrossRef] [PubMed]

227. Jówko, E.; Ostaszewski, P.; Jank, M.; Sacharuk, J.; Zieniewicz, A.; Wilczak, J.; Nissen, S. Creatine and beta-hydroxy-beta-methylbutyrate (HMB) additively increase lean body mass and muscle strength during a weight-training program. Nutrition 2001, 17, 558-566. [CrossRef]

228. Kreider, R.B.; Ferreira, M.; Wilson, M.; Grindstaff, P.; Plisk, S.; Reinardy, J.; Cantler, E.; Almada, A.L. Effects of creatine supplementation on body composition, strength, and sprint performance. Med. Sci. Sports Exerc. 1998, 30, 73-82. [CrossRef] [PubMed]

229. Brose, A.; Parise, G.; Tarnopolsky, M.A. Creatine Supplementation Enhances Isometric Strength and Body Composition Improvements Following Strength Exercise Training in Older Adults. J. Gerontol. Ser. A Biol. Sci. Med. Sci. 2003, 58, B11-B19. [CrossRef] [PubMed]

230. Chrusch, M.J.; Chilibeck, P.D.; Chad, K.E.; Davison, K.S.; Burke, D.G. Creatine supplementation combined with resistance training in older men. Med. Sci. Sports Exerc. 2001, 33, 2111-2117. [CrossRef] [PubMed]

231. Tarnopolsky, M.A.; Safdar, A. The potential benefits of creatine and conjugated linoleic acid as adjuncts to resistance training in older adults. Appl. Physiol. Nutr. Metab. 2008, 33, 213-227. [CrossRef] [PubMed]

232. Candow, D.G.; Little, J.P.; Chilibeck, P.D.; Abeysekara, S.; Zello, G.A.; Kazachkov, M.; Cornish, S.M.; Yu, P.H. Low-Dose Creatine Combined with Protein during Resistance Training in Older Men. Med. Sci. Sports Exerc. 2008, 40, 1645-1652. [CrossRef] [PubMed]

233. Bemben, M.; Witten, M.; Carter, J.; Eliot, K.; Knehans, A.; Bemben, D. The effects of supplementation with creatine and protein on muscle strength following a traditional resistance training program in middle-aged and older men. J. Nutr. Health Aging 2010, 14, 155-159. [CrossRef] [PubMed]

234. Eijnde, B.O.; Van Leemputte, M.; Goris, M.; Labarque, V.; Taes, Y.; Verbessem, P.; Vanhees, L.; Ramaekers, M.; Eynde, B.V.; Van Schuylenbergh, R.; et al. Effects of creatine supplementation and exercise training on fitness in men 55-75 year old. J. Appl. Physiol. 2003, 95, 818-828. [CrossRef] [PubMed]

235. Domingues-Faria, C.; Boirie, Y.; Walrand, S. Vitamin D and muscle trophicity. Curr. Opin. Clin. Nutr. Metab. Care 2017, 20, 169-174. [CrossRef]

236. Dawson-Hughes, B. Vitamin D and muscle function. J. Steroid Biochem. Mol. Biol. 2017, 173, 313-316. [CrossRef]

237. Bunout, D.; Barrera, G.; Leiva, L.; Gattás, V.; De La Maza, M.P.; Avendaño, M.; Hirsch, S. Effects of vitamin D supplementation and exercise training on physical performance in Chilean vitamin $\mathrm{D}$ deficient elderly subjects. Exp. Gerontol. 2006, 41, 746-752. [CrossRef] [PubMed]

238. Binder, E.F. Implementing a Structured Exercise Program for Frail Nursing Home Residents with Dementia: Issues and Challenges. J. Aging Phys. Act. 1995, 3, 383-395. [CrossRef]

239. Rodacki, C.L.; Rodacki, A.L.; Pereira, G.; Naliwaiko, K.; Coelho, I.; Pequito, D.; Fernandes, L.C. Fish-oil supplementation enhances the effects of strength training in elderly women. Am. J. Clin. Nutr. 2012, 95, 428-436. [CrossRef] [PubMed]

240. Cornish, S.M.; Chilibeck, P.D. Alpha-linolenic acid supplementation and resistance training in older adults. Appl. Physiol. Nutr. Metab. 2009, 34, 49-59. [CrossRef] [PubMed]

241. Rossato, L.T.; Schoenfeld, B.J.; De Oliveira, E.P. Is there sufficient evidence to supplement omega-3 fatty acids to increase muscle mass and strength in young and older adults? Clin. Nutr. 2019. [CrossRef] [PubMed]

242. Murphy, C.H.; Roche, H.M. Nutrition and physical activity countermeasures for sarcopenia: Time to get personal? Nutr. Bull. 2018, 43, 374-387. [CrossRef]

243. Law, T.D.; Clark, L.A.; Clark, B.C. Resistance Exercise to Prevent and Manage Sarcopenia and Dynapenia. Annu. Rev. Gerontol. Geriatr. 2016, 36, 205-228. [CrossRef] [PubMed]

244. Cruz-Jentoft, A.J.; Landi, F.; Schneider, S.M.; Zúñiga, C.; Arai, H.; Boirie, Y.; Chen, L.K.; Fielding, R.A.; Martin, F.C.; Michel, J.P.; et al. Prevalence of and interventions for sarcopenia in ageing adults: A systematic review. Report of the International Sarcopenia Initiative (EWGSOP and IWGS). Age Ageing 2014, 43, 748-759. [CrossRef]

245. Zão, A. Exercise for Sarcopenia in the Elderly: What Kind, Which Role? Res. Investig. Sports Med. 2018, 2. [CrossRef]

246. Helms, E.R.; Cronin, J.; Storey, A.; Zourdos, M.C. Application of the Repetitions in Reserve-Based Rating of Perceived Exertion Scale for Resistance Training. Strength Cond. J. 2016, 38, 42-49. [CrossRef] 
247. Molina, R.G.; Ruíz-Grao, M.C.; García, A.N.; Reig, M.M.; Víctor, M.E.; Izquierdo, M.; Abizanda, P.; Grao, M.C.R.; Redín, M.I.; Soler, P.A. Benefits of a multicomponent Falls Unit-based exercise program in older adults with falls in real life. Exp. Gerontol. 2018, 110, 79-85. [CrossRef] [PubMed]

248. Chalé, A.; Cloutier, G.J.; Hau, C.; Phillips, E.M.; Dallal, G.E.; Fielding, R.A. Efficacy of whey protein supplementation on resistance exercise-induced changes in lean mass, muscle strength, and physical function in mobility-limited older adults. J. Gerontol. A Biol. Sci. Med. Sci. 2013, 68, 682-690. [CrossRef] [PubMed]

249. Reeves, N.D.; Maganaris, C.N.; Narici, M.V. Effect of strength training on human patella tendon mechanical properties of older individuals. J. Physiol. 2003, 548, 971-981. [CrossRef] [PubMed]

250. Singh, N.A.; Quine, S.; Clemson, L.M.; Williams, E.J.; Williamson, D.A.; Stavrinos, T.M.; Grady, J.N.; Perry, T.J.; Lloyd, B.D.; Smith, E.U.; et al. Effects of High-Intensity Progressive Resistance Training and Targeted Multidisciplinary Treatment of Frailty on Mortality and Nursing Home Admissions after Hip Fracture: A Randomized Controlled Trial. J. Am. Med Dir. Assoc. 2012, 13, 24-30. [CrossRef] [PubMed]

251. Liao, C.D.; Chen, H.C.; Huang, S.W.; Liou, T.H. The Role of Muscle Mass Gain Following Protein Supplementation Plus Exercise Therapy in Older Adults with Sarcopenia and Frailty Risks: A Systematic Review and Meta-Regression Analysis of Randomized Trials. Nutrients 2019, 11, 1713. [CrossRef] [PubMed]

252. Volkert, D.; Beck, A.M.; Cederholm, T.; Cruz-Jentoft, A.; Goisser, S.; Hooper, L.; Kiesswetter, E.; Maggio, M.; Raynaud-Simon, A.; Sieber, C.C.; et al. ESPEN guideline on clinical nutrition and hydration in geriatrics. Clin. Nutr. 2019, 38, 10-47. [CrossRef] [PubMed]

(C) 2019 by the authors. Licensee MDPI, Basel, Switzerland. This article is an open access article distributed under the terms and conditions of the Creative Commons Attribution (CC BY) license (http://creativecommons.org/licenses/by/4.0/). 